OPEN ACCESS

Edited by:

Miroslav Harjaček,

United Arab Emirates University,

United Arab Emirates

Reviewed by:

Ana Filipa Mourão,

Hospital de Egas Moniz, Portugal

Robert Allen Colbert,

National Institute of Arthritis and Musculoskeletal and Skin Diseases

(NIAMS), United States

${ }^{*}$ Correspondence:

Corinne Fisher

corinne.fisher@ucl.ac.uk

tThese authors share senior authorship

Specialty section:

This article was submitted to Rheumatology,

a section of the journal

Frontiers in Medicine

Received: 16 March 2021 Accepted: 26 April 2021

Published: 31 May 2021

Citation:

Fisher C, Ciurtin C, Leandro M, Sen D and Wedderburn LR (2021) Similarities and Differences Between Juvenile and Adult Spondyloarthropathies.

Front. Med. 8:681621.

doi: 10.3389/fmed.2021.681621

\section{Similarities and Differences Between Juvenile and Adult Spondyloarthropathies}

\author{
Corinne Fisher ${ }^{1,2,3 *}$, Coziana Ciurtin ${ }^{1,2,4}$, Maria Leandro ${ }^{1,2,4}$, Debajit Sen ${ }^{1,2,3 \dagger}$ and \\ Lucy R. Wedderburn ${ }^{1,5,6 t}$
}

${ }^{1}$ Centre for Adolescent Rheumatology Versus Arthritis at University College London, University College London Hospital and Great Ormond Street Hospital, London, United Kingdom, ${ }^{2}$ Department of Adolescent Rheumatology, University College London Hospitals NHS Foundation Trust, London, United Kingdom, ${ }^{3}$ National Institute for Health Research University College London Hospitals Biomedical Research Centre, London, United Kingdom, ${ }^{4}$ Division of Medicine, Department of Rheumatology (Bloomsbury), University College London, London, United Kingdom, ${ }^{5}$ National Institute for Health Research Biomedical Research Centre at Great Ormond Street Hospital for Children, London, United Kingdom, ${ }^{6}$ Infection, Immunity \& Inflammation Teaching and Research Department University College London Great Ormond Street Institute of Child Health, London, United Kingdom

Spondyloarthritis (SpA) encompasses a broad spectrum of conditions occurring from childhood to middle age. Key features of SpA include axial and peripheral arthritis, enthesitis, extra-articular manifestations, and a strong association with HLA-B27. These features are common across the ages but there are important differences between juvenile and adult onset disease. Juvenile SpA predominantly affects the peripheral joints and the incidence of axial arthritis increases with age. Enthesitis is important in early disease. This review article highlights the similarities and differences between juvenile and adult SpA including classification, pathogenesis, clinical features, imaging, therapeutic strategies, and disease outcomes. In addition, the impact of the biological transition from childhood to adulthood is explored including the importance of musculoskeletal and immunological maturation. We discuss how the changes associated with adolescence may be important in explaining age-related differences in the clinical phenotype between juvenile and adult SpA and their implications for the treatment of juvenile SpA.

\footnotetext{
Keywords: juvenile spondyloarthropathy, enthesitis related arthritis, adolescence, enthesitis, adult spondyloarthropathy
}

\section{INTRODUCTION}

The spondyloarthropathies (SpAs) are a heterogeneous group of inflammatory arthropathies affecting both the peripheral and axial joints. In adults the most common form of SpA is axial SpA (axSpA) which includes ankylosing spondylitis (AS) and non-radiographic axSpA (nraxSpA). Other forms of SpA include psoriatic arthritis, enteropathic arthritis, reactive arthritis, and undifferentiated SpA (1). Apart from axial and peripheral arthritis, common clinical features across all these subtypes can include enthesitis, dactylitis, and extra-articular manifestations such as acute anterior uveitis, inflammatory bowel disease (IBD), and psoriasis. There is a strong association between these conditions and the major histocompatibility complex (MHC) class 1 antigen human leucocyte antigen (HLA)-B27 although the mechanism for this association remains unclear (2). The prevalence of SpA varies widely by geographical area with the highest rates reported in North America and Europe which may correspond to the prevalence of HLA-B27 (3). 
The onset of SpA occurs across a broad age range from childhood to adolescence and adulthood with a peak incidence in late adolescence and early adulthood (4). Although the common features remain the same, the clinical phenotype is different across the ages with peripheral arthritis and enthesitis predominant in juvenile SpA (JSpA) and axial manifestations more typical of adult onset disease. JSpA is classified differently from adult $\mathrm{SpA}$ as enthesitis related arthritis (ERA) which encompasses both axial and peripheral arthritis, and juvenile onset psoriatic arthritis, both of which are classified within the umbrella term juvenile idiopathic arthritis (JIA) (5).

The reasons for differences in clinical phenotype between adult onset disease and JSpA are not well-understood but may be due to the changes associated with musculoskeletal maturation and development of the immune system during childhood and adolescence. This review will discuss the similarities and differences between JSpA and adult onset SpA and highlight areas where better alignment between paediatric and adult disease would enhance research and clinical care.

\section{CLASSIFICATION CRITERIA}

Adult SpA is classified by the Assessment of SpA International Society (ASAS) criteria which have been developed separating axial and peripheral SpA but encompassing the broad spectrum of disease including psoriatic arthritis, enteropathic arthritis, and reactive arthritis (Table 1) (6). There is a focus on the range of typical clinical features associated with $\mathrm{SpA}$, including the association with HLA B27, enthesitis, and extra-articular manifestations. In addition, the inclusion of magnetic resonance imaging (MRI) assessment of the sacroiliac joints (SIJs) enables much earlier diagnosis of axial disease (including nr-axSpA) and therefore earlier treatment. This is in contrast to the older but still widely used modified New York criteria, which define AS by the grading of sacroiliitis using plain radiographs (7) and therefore capture more longstanding disease (8).

In contrast to adult SpA, JSpA is classified as part of the International League of Associations for Rheumatology (ILAR) classification criteria for JIA. JIA encompasses the broad spectrum of idiopathic inflammatory arthritis occurring before the age of 16 years, divided into seven mutually exclusive subtypes. Six subtypes are defined according to the pattern of joint involvement and extra-articular features during the first 6 months of disease. Those patients who do not meet the classification criteria for one of these six groups, or who meet the criteria for more than one subtype are classified in the seventh group as "undifferentiated JIA" (5). In contrast to adult SpA, patients with JSpA are not confined to one group but are divided between three subtypes of JIA: ERA, juvenile onset psoriatic arthritis and undifferentiated JIA (Table 1). The term ERA was developed in recognition of the distinct clinical presentation of childhood disease and replaced others including seronegative enthesopathy and arthropathy (SEA) (9), juvenile AS and JSpA.

There are well-recognised problems with the ILAR criteria (10-12). Compared to the ASAS criteria, the ILAR criteria lack the differentiation between axial and peripheral disease which is important for disease course and outcome. There is no inclusion of MRI assessment or inflammatory markers. The criterion of male sex in the ERA classification criteria increases the chance of diagnosis in males and leads to more females being classified as other JIA subtypes such as oligoarticular JIA. This may not be appropriate given recent evidence from studies in adults that the male predominance in SpA has significantly reduced in recent years (13). Patients with psoriatic arthritis and with a family history of psoriasis in a first degree relative are separated into the psoriatic arthritis category; despite these patients often having an overlapping disease phenotype with ERA (12). In addition, patients with enteropathic arthropathy and reactive arthritis are excluded from the psoriatic arthritis subtype (although are included in the ERA subtype) (5) even though they would all be considered as having SpA according to the adult ASAS criteria. A study of adult patients diagnosed with ERA in childhood found that $95 \%$ fulfilled the classification criteria for adult SpA (14).

In practice, the ILAR criteria result in a high proportion of patients with JSpA being classified in the undifferentiated JIA group and this, and the other reasons above, has led to a resurgence of the use of the term JSpA. The difficulties with the classification criteria and lack of alignment between paediatric and adult classification criteria has hampered the development of collaborative research studies in this field resulting in relatively few studies examining the clinical patterns, outcomes, and pathogenesis of JSpA.

\section{PATHOGENESIS}

Research investigating the pathogenesis of JSpA is sparse compared to the extensive study of the pathogenesis of adult SpA. It is assumed that the pathogenesis is the same but studies including or comparing patients with adult SpA and JSpA are rare. Patient numbers in studies of JSpA are often small or are combined with other JIA subtypes and therefore it is difficult to draw conclusions from the current published data.

HLA-B27 is strongly associated with both adult SpA and JSpA and many subtypes exist. The most common allele is HLA-B27:05 which is associated with an increased risk of SpA across all races, ethnicities and ages (15). The HLA-B27:04 allele, which confers an increased risk in Eastern Asians was found to be the most prevalent subtype in a population of south Indian patients with ERA (16). Despite the strong association with SpA and in particular AS, HLA-B27 is only estimated to account for around $20 \%$ of the total heritability of AS $(2,17,18)$ with other genetic risk alleles accounting for a further $8 \%(19)$. Many genetic variations related to pro-inflammatory pathways known to be associated with SpA have been found in patients with AS (20). After HLA-B27, genetic variations in endoplasmic reticulum aminopeptidase (ERAP) 1 are the most commonly recognised in adults (21) and have also been found in patients with ERA (22). Variations in the IL23 receptor (IL23R) gene are strongly associated with AS and other related conditions such as psoriasis and IBD (23) and have also been linked with 
TABLE 1 | Classification criteria for the diagnosis of adult SpA and JSpA.

\section{ASAS CRITERIA}

\section{Axial SpA}

For patients with $\geq 3$ months back pain (with/without peripheral

manifestations), aged $<45$ years

Sacroilitis on imaging plus $\geq 1 \mathrm{SpA}$ feature $\quad$ OR $\quad$ HLA-B27 plus $\geq 2$ other

SpA features:

- Inflammatory back pain

- Arthritis

- Enthesitis (heel)

- Uveitis

- Dactylitis

- Psoriasis

- Crohn's disease/Ulcerative Colitis

- Good response to NSAIDs

- Family history of SpA

- HLA-B27

- Elevated CRP

\section{Peripheral SpA}

For patients with peripheral manifestations only

Arthritis or enthesitis or dactylitis plus

$\geq 1$ SpA feature:

- Uveitis

- Psoriasis

- Crohn's disease/ Ulcerative Colitis

- Preceding infection

- HLA-B27

- Sacroilitis on imaging

$\mathrm{OR}$

$\geq 2$ other SpA features:

- Arthritis

- Enthesitis

- Dactylitis

- Inflammatory back pain ever

- Family history of SpA

\section{ILAR JIA CRITERIA}

\section{ERA}

Arthritis AND enthesitis

OR

Arthritis OR Enthesitis plus $\geq 2$ of:

- Current or past sacroiliac joint tenderness and/or inflammatory

lumbosacral pain

- HLA-B27

- Onset of arthritis in a male $>6$ years

old

- Acute anterior uveitis

- History of AS, ERA, sacroiliitis with inflammatory bowel disease, reactive arthritis or acute anterior uveitis in a first degree relative

Exclusions:

- Psoriasis or a history of psoriasis in the patient or a first degree relative

- Presence of immunoglobulin M rheumatoid factor on at least two occasions 3 months apart

- Presence of systemic JIA in the patient

\section{Juvenile onset psoriatic arthritis}

Arthritis AND psoriasis

OR

Arthritis plus $\geq 2$ of:

- Dactylitis

- Nail pits or onycholysis

- Family history of psoriasis in a first degree relative

ASAS, Assessment of SpA International Society; ILAR, International League of Associations for Rheumatology; JIA, juvenile idiopathic arthritis.

juvenile onset psoriatic arthritis but not ERA (22). Differentially expressed genes in the mitogen-activated protein kinase (MAPK) pathway have been identified in both adult SpA and JSpA (24-26). Thus, similarities exist in the genetic associations between adult onset SpA and JSpA, but study of other genetic variants in the paediatric population is limited by low study participant numbers compared to the large numbers studied in adult SpA.

The interleukin (IL)23/IL17 pathway has been strongly implicated in the pathogenesis of SpA. IL23 plays a crucial role in enthesitis, the primary pathological feature of SpA (27). Increased production of IL23 is noted from macrophages of adult patients with AS compared to healthy volunteers (28) and IL23 is found in higher concentrations in the inflammatory lesions from facet joints of patients with AS compared to those with osteoarthritis (29). IL23 is less well-studied in ERA. One study demonstrated higher levels of IL23-producing intermediate monocytes in patients with ERA (30) but serum levels were no different between patients and healthy controls (31). Studies of serum IL23 levels in adult SpA have produced mixed 
results with some reporting higher concentrations and others no difference between patients and healthy controls (32-35). Recent studies suggest that IL23 may be critical in the early phases of disease pathogenesis (36) and therefore further investigation is important to understand its role in the pathogenesis of JSpA.

IL23 is crucial for the expansion and survival of Th17 cells (37) which are increased in the peripheral blood and synovial fluid of adult patients with $\operatorname{SpA}(38,39)$. IL17 has also been found at higher concentrations in the serum and synovial fluid of adult patients with active SpA $(40,41)$. However, Th17 levels were not found in higher numbers in a small study of patients with ERA compared to controls (42) and levels of serum IL17 were no different between patients and healthy controls in another study by the same group (31). However, a subset of Th17 cells expressing the killer immunoglobulin receptor (KIR)3DL2, which interacts with aberrant forms of HLA-B27 and promotes Th17 cell survival, is increased in patients with ERA as well as adults with SpA compared to healthy controls (43). Levels of IL27, a regulatory cytokine in the IL23/17 pathway, are reduced in patients with ERA and this negatively correlates with Th17 cell concentration, suggesting dysregulation of the IL23/IL17 pathway is important in ERA (31). IL27 has been implicated in adult SpA through genetic studies (20).

Other pro-inflammatory cytokines such as tumour necrosis factor (TNF), IL6, IL1, and granulocyte-macrophage colonystimulating factor (GMCSF) have also been implicated in the pathogenesis of SpA (44). The use of TNF blockade is highly effective in treating both JSpA and adult SpA therefore implying the importance of TNF in the pathogenesis of SpA across the ages. One study of synovial fluid TNF levels did not find any differences in levels between patients with ERA and another subtype of JIA (polyarticular JIA) or rheumatoid arthritis (45) but this is perhaps not surprising given the efficacy of TNF blockade across the inflammatory arthritides. In the same study, levels of IL6 were found to be higher in patients with ERA compared to those with polyarticular JIA. Increased serum levels of IL6 are found in patients with AS $(46,47)$ and IL6 is found in the inflamed SIJs of patients with AS (48). However, clinical trials of IL6 blockade in adults with SpA have failed to show clinical benefit (49) and therefore the significance of this is unclear. GMCSF has been implicated in the pathogenesis of inflammatory arthritis and in particular in the pathogenicity of Th17 cells (50) perhaps through a synergistic relationship with $\operatorname{IL} 23(51,52)$. Higher numbers of GMCSF-producing Th17 cells are found in the peripheral blood of adult patients with SpA compared to patients with rheumatoid arthritis and healthy volunteers (53). GMCSF has also been implicated in oligoarticular and polyarticular course JIA but has not been studied specifically in JSpA (54).

Higher levels of interferon gamma (IFN $\gamma$ ) are found in synovial fluid from patients with ERA compared to those with polyarticular JIA (45). This is in contrast to adult SpA where lower levels of IFN $\gamma$ are found in the synovium compared to those with rheumatoid arthritis and studies suggest dysregulation of IFN $\gamma$ genes (55-57). Further study in both adult SpA and JSpA is important to understand the role of IFN $\gamma$ in the pathogenesis of these conditions.
Chemokines have been studied in adult SpA as potential biomarkers for active disease and radiographic progression. Serum MMP3 levels have been shown to be higher in adult patients compared to healthy volunteers (58). In some studies, MMP3 levels reflect disease activity and may also predict structural damage (59). In contrast, for patients with ERA, MMP3 levels were found to be no different to healthy volunteers but did correlate with disease activity (60). MMP8 and 9 have been shown to be closely associated with disease activity in adult SpA in one study (61) but have not been studied in JSpA.

Another potential biomarker studied in both adult and JSpA is calprotectin or myeloid-related protein (MRP) 8/14. Serum levels are elevated in patients with SpA and may correlate with disease activity. High levels at baseline may predict radiographic progression and levels reduce on treatment with TNF inhibitors (62-65). Similarly in JSpA, plasma levels have been shown to be higher in patients compared to healthy volunteers; high levels correlate with active disease and reduce in those who respond to treatment (66). MRP8/14 is helpful in predicting response to treatment in patients with JIA $(67,68)$. In addition, faecal calprotectin is an established biomarker of disease activity in inflammatory bowel disease (69) and is elevated in adult patients with SpA (70). One small study of patients with ERA demonstrated higher levels compared to disease control patients with connective tissue diseases but further study is needed (71).

Evidence for the involvement of gut flora in the pathogenesis of SpA dates back many years with gram negative bacteria implicated in particular in both adult SpA (72-75) and JSpA (76). Microbes found in the gut shape host immune response from an early age (77) and several studies have shown differences in the gut microbiome between patients with SpA and healthy controls. A study by Costello et al. found differences in certain families of bacteria from terminal ileal biopsies from patients with AS (increases in Lachnospiraceae, Ruminococcaceae, Rikenellaceae, Porphyromonadaceae and Bacteroidaceae and decreases Veillonellaceae and Prevotellaceae) compared to healthy volunteers (78). Another study demonstrated an increase in Ruminococcus gnavus in faecal DNA from adult patients with $\mathrm{SpA}$ compared to those with rheumatoid arthritis and healthy volunteers (79). A large Norwegian cohort study revealed increased Proteobacteria, Enterobacteriaceae, Bacilli, Streptococcus species, and Actinobacteria, but lower abundance of Bacteroides and Lachnospiraceae in patients with AS compared to healthy volunteers. A link with raised faecal calprotectin was observed in patients with a lower abundance of certain bacterial species with anti-inflammatory properties (80). The microbiome has also been studied in JSpA with one study of Indian patients showing similar findings to studies in adult SpA with increases in Bacteroidaceae and Enterobacteriaceae families and a reduction in the Prevotellaceae family in patients compared to healthy controls. A study of both adult patients with SpA and patients with ERA found that a strain of the anti-inflammatory bacterial family Faecalibacterium prausnitzii was reduced in both patients with ERA and SpA. However, a higher abundance of Bacteroides was noted in patients with ERA compared to SpA (81) and this has also been found in other JIA subtypes (82). The presence of HLA-B27 appears to 
influence the gut microbiome (83). In addition, changes in the gut microbiome may result in upregulation of Toll Like receptors (TLRs) causing an inflammatory cascade and the production of pro-inflammatory cytokines (84). The expression of TLRs 2 , 4 , and 5 is upregulated in the synovium and peripheral blood mononuclear cells (PBMCs) of patients with SpA (85-87). Upregulation of TLRs 2 and 4 has also been found in patients with ERA (88).

Therefore, despite the similarities between the pathogenesis of adult SpA and JSpA, some differences exist. These may be explained by the lack of studies directly comparing adult SpA and JSpA or are perhaps due to lower patient numbers in studies of JSpA. However, a study comparing synovial biopsies in patients with JSpA, including both patients with ERA and juvenile onset psoriatic arthritis, to biopsies from patients with adult $\mathrm{SpA}$ found similarities but also marked differences. In particular, in JSpA there was a stronger lining layer hyperplasia and the number of infiltrating CD163+ macrophages were lower which meant JSpA failed to classify in the SpA group by class prediction analysis. Instead, there was partial overlap with other JIA subtypes suggesting that age may strongly influence the pathogenenic features of SpA (89). Factors such as changes in the immune system and gut microbiome with age, which have been demonstrated in detailed studies of healthy subjects and in smaller cohorts of patients $(90,91)$ may give rise to some of the differences described above and distinct clinical phenotype of JSpA compared to adult SpA. Some specific immune agerelated changes have been demonstrated to occur at the time of puberty in both boys and girls such as IFN production in response to TLR stimulation (92). However, how these age-related immune function changes relate to the differences between JSpA compared to adult SpA, remains an area for future investigation.

\section{CLINICAL FEATURES}

Multiple studies across different countries clearly demonstrate the predominance of peripheral arthritis and enthesitis in JSpA compared to adult $\mathrm{SpA}$ where axial arthritis is the most common clinical feature at onset and throughout disease course (93-99). Shoulder and hip joint involvement are also more common in JSpA (100) and the most frequently involved joints in JSpA include the knee (40-50\%), ankle (25-40\%), and hip (30-40\%) $(101,102)$. As in adult SpA, enthesitis commonly affects the lower limb in JSpA and, in particular, the inferior pole of the patella, plantar fascial insertion into the calcaneum, Achilles tendon and the tibial tuberosity (103-105). In one study, enthesitis was shown to be present in $83 \%$ of patients with ERA on ultrasound but clinical examination yielded a much lower detection rate (106). Enthesitis is a key feature of early disease in SpA and the lack of sensitivity of clinical examination may contribute to diagnostic delay. This has been identified to be longer in patients with JSpA compared to adult SpA in several studies $(96,97,107)$ although not consistently (95).

In general, comparisons between JSpA and adult SpA have not identified significant differences in the male to female ratio,
TABLE 2 | Comparison of adult and paediatric disease activity scores for SpA.

\begin{tabular}{ll}
\hline $\begin{array}{l}\text { AS disease activity score } \\
\text { (ASDAS) }\end{array}$ & $\begin{array}{l}\text { Juvenile SpA disease activity } \\
\text { (JSpADA) index }\end{array}$ \\
\hline - Back pain & - Active joint count \\
- Peripheral pain/swelling & - Active enthesitis count \\
- Morning stiffness & - Patient pain score \\
- Patient global assessment & - CRP/ESR \\
- CRP/ESR & - Morning stiffness \\
& - Clinical sacroilitis \\
& - Uveitis \\
& - Back mobility (modified \\
& Schober's test) \\
\end{tabular}

CRP, C reactive protein; ESR, erythrocyte sedimentation rate.

HLA-B27 status, family history of HLA-B27-related disease and extra-articular manifestations such as psoriasis and inflammatory bowel disease. An increase in uveitis has been reported in JSpA compared to adult SpA in a small number of studies $(97,98)$ but this was not confirmed in a recent meta-analysis (108).

\section{ASSESSMENT OF DISEASE ACTIVITY}

Disease activity is measured differently in adult SpA and JSpA. The AS disease activity score (ASDAS) is now the most widely used assessment of disease activity in adults (109) and includes patient-reported measures of back pain, morning stiffness, peripheral joint pain and swelling, global assessment, and a measure of inflammation (either ESR or CRP) (Table 2). It has validated classifications for inactive, low, high, or very high disease activity (110) but has not been validated in JSpA. Other disease activity measures in use in adults include the Bath Ankylosing Spondylitis Disease Activity Index (BASDAI) (111) and the Bath Ankylosing Spondylitis Functional Index (BASFI) (112). These have been validated in children and young people but focus on spinal disease and underestimate enthesitis, therefore may not accurately reflect disease activity $(113,114)$.

Until recently, disease activity in JSpA was measured using the same scores used for all JIA subtypes. The two scores in common use are the juvenile arthritis disease activity score (JADAS) which measures four domains including physician global assessment, patient global assessment, active joint count, and an inflammatory marker (either CRP or ESR) (115) and the core outcome variables which include a physician global assessment, patient/ parent global assessment, functional status, inflammatory marker (ESR), number of joints with active arthritis, and number of joints with restricted range of movement (116). However, neither of these measures assesses enthesitis or axial arthritis and therefore disease activity in patients with JSpA is likely to be underestimated. The need for a dedicated disease activity score for JSpA has been met with the development of the juvenile SpA disease activity (JSpADA) index. This assesses 8 domains including active joint count, enthesitis count, patient pain assessment, inflammation (either CRP or ESR), morning stiffness, clinical evaluation of sacroiliitis, uveitis, and back mobility measured by the modified Schober's test 
(Table 2). Necessarily, for the paediatric population, it contains more objective measures and fewer patient reported measures compared to the ASDAS. It has undergone preliminary validation in a patient population with a mean age of 12 years and appears to be superior to other JIA disease activity measures in assessing disease activity in ERA (117). It has been subsequently validated in other populations with an older mean age (14.3 years) (113) and has started to gain wider use.

Further measures of disease severity in adult SpA include the Bath Ankylosing Spondylitis Metrology Index (BASMI) which measures spinal movement and the modified Stoke AS Severity Score (mSASSS) which evaluates disease severity on plain radiographs. However, neither of these measures is useful in JSpA as they focus predominantly on axial disease and are not sensitive for early SpA or peripheral arthritis $(118,119)$. Radiographic changes seen on the mSASSS are a reflection of late disease and plain radiographs of the SIJ in children and young people are often misleading with frequent false negative and false positive results (120).

Imaging, in particular MRI, is useful to assess disease activity and severity in axial disease, peripheral arthritis, and enthesitis in both adult SpA and JSpA. MRI features of axial SpA include both inflammatory lesions such as bone marrow oedema and osteitis and structural lesions such as erosions, sclerosis, and bony ankylosis. These features alone lack specificity and must be interpreted together with the clinical picture (121-123). Caution is needed in the interpretation of MRI of the SIJs in children and young people as significant variability is found (124). Features of sacroiliitis are comparable to those found in adults (125) although diagnostic criteria used in adults may have a lower sensitivity in children and young people (126). More significantly, MRI images of normal marrow and cartilage development can be mistaken for bilateral sacroiliitis. In particular, bilateral symmetrical metaphyseal high signal and cortical irregularities along the ilial margin of the SIJ which occur with normal maturation may appear similar to sacroiliitis leading to misdiagnosis of JSpA $(127,128)$. This was illustrated in a multicentre study in which significant variation in the interpretation of inflammatory and structural lesions on MRI of the SIJ in patients with JSpA was seen giving rise to frequent false positive results (129). Another single centre study showed low to moderate inter-reporter reliability when interpreting SIJ MRI in children and young people (130). Clinical examination, back pain and buttock pain all have a low sensitivity for identifying sacroiliitis in children and young people (131) and therefore novel MRI techniques which help to distinguish true sacroiliitis from the changes associated with normal maturation in children and young people are important (132).

Other imaging modalities such as ultrasound are helpful to assess enthesitis which may be difficult to detect clinically (121, 133). However, again, caution is needed in the interpretation of ultrasound findings in children and young people. There is significant variability in entheseal thickness with growth and development, making it difficult to define a "normal range." One study in healthy children revealed a correlation between entheseal thickness and age (134). However, another study found a correlation with weight. This study also noted that boys tended to have thicker entheses than girls but significant variability was found even between left and right sides in the same subject (135).

\section{TREATMENT}

Multidisciplinary management is important in the treatment of both adult SpA and JSpA. There is good evidence for physiotherapy intervention in adult SpA but no studies in JSpA. However, the impact of diagnosis and symptoms (as well as delayed diagnosis) is often significant on psychosocial well-being as well as education and physical functioning in children and young people $(136,137)$.

Non-steroidal anti-inflammatory drugs (NSAIDs) are the first line pharmacological therapy in adult $\mathrm{SpA}$ and improve symptom in both axial and peripheral arthritis (138). There is some evidence to suggest prolonged, continuous use of NSAIDs may slow radiographic progression in adult SpA $(139,140)$ but this was not confirmed in a prospective study (141). NSAIDs are also frequently used as first line therapy in JSpA $(105,142)$ but there is no evidence for continuous or prolonged treatment or of the effect on disease progression. Whilst rarely used in adult $\mathrm{SpA}$, local, or systemic corticosteroids are sometimes used as a holding measure before treatment with either DMARDs or TNF inhibitors is effective in JSpA, although they may not be as effective as in other JIA subtypes.

Conventional disease modifying anti-rheumatic drugs (DMARDs) such as methotrexate and sulfasalazine are only used if there is peripheral arthritis in adult SpA $(143,144)$ as they are ineffective in axial disease $(145,146)$. However, DMARDs are commonly used in JSpA because of the high prevalence of peripheral arthritis and enthesitis. Although methotrexate is the most commonly used DMARD for JIA (including ERA and psoriatic arthritis), there is no specific evidence for the use of methotrexate in JSpA as patients with ERA and psoriatic arthritis were excluded from a large trial of methotrexate in patients with JIA (147). Sulfasalazine was found to be effective in a randomised double blind placebo controlled trial in 33 patients with JSpA after 26 weeks treatment (148).

When the treatments above do not establish adequate disease control, TNF inhibitors are highly effective treatments for adult SpA and JSpA, especially for axial arthritis where conventional DMARDs are not effective. In adults, numerous randomised controlled trials (RCTs) have provided good evidence for the efficacy of etanercept (149), adalimumab (150), infliximab (151), golimumab (152), and certolizumab (153) with reported response rates of around $60 \%$. Until recent years, the efficacy of TNF inhibitors in JSpA was established through open label studies, retrospective analyses and reports from registries. Treatment regimens for JSpA were often the same as those of other JIA subtypes without stratification between axial and peripheral disease. However, two RCTs of treatment in JSpA have been published demonstrating the efficacy of etanercept (154) and adalimumab (155). Adalimumab is effective for the treatment of axial disease in JSpA (156) and for treating extra-articular manifestations including uveitis (157), inflammatory bowel disease (158), and psoriasis (159). Of the other TNF inhibitors, 
only Infliximab has been studied specifically in JSpA in one randomised trial (160). There does not appear to be any difference in the efficacy of the different TNF inhibitors in the treatment of adult SpA and JSpA but there is evidence that the monoclonal antibodies (adalimumab, infliximab, golimumab, certolizumab) are superior to etanercept in the treatment of extra-articular manifestations and therefore may be used in preference when these are present $(161,162)$.

In both adult SpA and JSpA, there is evidence that early treatment with TNF inhibitors may be more beneficial with the possibility of partial remission demonstrated in adults with axSpA $(163,164)$ and a greater improvement in disease activity and lower reported pain scores in patients with JSpA (165). Following the initiation of TNF inhibitors, sustained remission without treatment is rare in both adult SpA and JSpA, even in those treated early, with most patients relapsing within a year of treatment cessation (166-169). However, tapering treatment by increasing the interval between doses or reducing the dose may be possible (170-172).

Despite the clear benefit of treatment with TNF inhibition, the effect on radiographic progression has been debated in adults with axSpA. Several studies have demonstrated continued new bone formation despite treatment (173-175). However, more recent studies do suggest that TNF inhibitors slow radiographic progression, especially if used early in disease, suggesting a potential early window of opportunity for treatment (176-179). In JSpA, one small study demonstrated progression of sacroiliitis despite treatment with TNF inhibitors (180) and SIJ bony ankylosis occurs with rates correlating with the length of time taken to start treatment with TNF inhibition (181).

Given the importance of the IL23/IL17 pathway in the pathogenesis of SpA, biologics inhibiting this pathway are of particular interest for the treatment of patients with SpA. Ustekinumab, an inhibitor of IL23, was initially found to be effective in an open-label study of patients with active AS (182). However, no benefit was found in two subsequent RCTs, and the studies were terminated (183). Ustekinumab is an effective treatment for psoriatic arthritis (184) including axial arthritis in this group, and is also an effective treatment of enthesitis in patients with psoriatic arthritis (185). In JSpA, a case series of five patients treated with Ustekinumab demonstrated an improvement in disease activity in all but one patient (186) but no RCTs have been carried out. Other inhibitors of IL23, including guzelkumab, are effective treatments for psoriasis and psoriatic arthritis and demonstrate significant improvement in enthesitis (187). However, no benefit has been found in the treatment of axSpA and there have been no studies in JSpA (188). Given that enthesitis is an early feature of SpA and that there is a high prevalence in JSpA, investigating the effect of IL23 inhibition in patients with JSpA should be considered.

Treatments inhibiting IL17 have proved more effective than those inhibiting IL23 in adult SpA and for axSpA in particular, with response rates similar to those of TNF inhibitors (189). Secukinumab is now an established treatment for adults with SpA (including psoriatic arthritis) (190) and a clinical trial in JSpA has recently been completed (ClinicalTrials.gov: NCT03031782). Other agents blocking IL17 such as ixekizumab and brodalumab have proved effective for axSpA and psoriatic arthritis (191-193) and a clinical trial of ixekizumab is planned in JSpA (ClinicalTrials.gov: NCT04527380). It has been suggested that IL17 inhibitors may slow radiographic progression more effectively than TNF inhibitors (194) but this needs further investigation with "head to head" studies.

JAK inhibitors are another emerging treatment for SpA and Tofacitinib has shown similar efficacy to TNF inhibitors in adult SpA, including axSpA and psoriatic arthritis (195, 196). Clinical trials of JAK inhibitors are underway in patients with JIA, including patients with ERA and psoriatic arthritis subtypes (ClinicalTrials.gov: NCT02592434, ClinicalTrials.gov: NCT03773978). GMCSF inhibition is also under investigation in axSpA but not yet in JSpA (ClinicalTrials.gov: NCT03622658). Other biologic agents including IL6 and IL1 receptor inhibitors (197, 198), abatacept (199), and rituximab (200) have proved ineffective for the treatment of adult SpA and have not been studied in JSpA.

\section{OUTCOMES}

Factors associated with a worse prognosis in adult patients with SpA have historically included the presence of hip arthritis and three or more of persistently raised ESR, unresponsiveness to NSAIDs, limitation of the lumbar spine movement, dactylitis, oligoarthritis, or onset younger than 16 years (201). AxSpa, the most studied form of $\mathrm{SpA}$, is noted to be more common in men and is associated with higher levels of inflammation, more structural changes on MRI, higher levels of peripheral arthritis and enthesitis, and more uveitis compared to those with nraxSpA (202). HLA-B27 status and severe inflammation on SIJ MRI in early disease are predictors of more severe radiographic changes after 8 years follow up (203). Obesity is associated with a worse outcome in axSpA (204). Differences in outcomes between males and females are reported (13).

There are relatively few outcome studies in JSpA and most compare JSpA to other JIA subtypes. These studies demonstrate that JSpA, in particular ERA, has low rates of remission and a worse prognosis compared to most other subtypes $(205,206)$. Despite treatment with TNF inhibitors and good initial response rates, this has not changed in recent years with ongoing disease activity seen in around $60 \%(142,207)$. Higher pain scores and worse levels of physical function are also seen in patients with ERA compared to other JIA subtypes (208-210). Factors influencing prognosis in JSpA are similar to those in adult SpA. HLA-B27 in patients with JIA is associated with an increased chance of developing inflammatory lower back pain and, in males, enthesitis, and a lower chance of clinical remission after 8 years $(211,212)$. Other factors associated with a worse prognosis include male sex, ankle and hip arthritis and persistently raised inflammatory markers (206). Two studies comparing JSpA and adult $\mathrm{SpA}$ reported a greater requirement for hip arthroplasty in patients with JSpA $(213,214)$. 


\section{THE EFFECT OF ADOLESCENCE: SEX HORMONES AND MECHANICAL STRESS}

The peak age of onset of JSpA differs from most other JIA subtypes and corresponds to the onset of adolescence. Some HLA-alleles have been associated with early childhood arthritis. However, HLA-B27 appears to confer protection from the development early onset disease and has been associated with later onset arthritis in children which may explain the peak age of onset in early adolescence (215).

Increased oestrogen and progesterone production in females and increased testosterone production in males occur at the time of puberty. The effect of sex hormones on the immune system is well-documented and key changes in adolescence include higher levels of monocytes in males compared to females (216) and higher levels of T cells in females (217). The gut microbiome is also unique in adolescents and increased diversity of microbial species has been noted compared to adults. Sex hormones are also associated with differences in gut microbiota between males and females (218). Sexual dimorphism in adult SpA is wellrecognised with higher levels of circulating Th17 cells in males with AS, in addition to higher serum levels of IL17, TNF, and IL18 $(219,220)$. Differences are also noted in clinical outcomes and response to treatment. In SpA, male sex is associated with more extensive bone marrow oedema of the SIJs (221) and a worse radiographic outcome (222-224). However, female sex is associated with higher disease activity and pain scores (222, 223, 225-227), less severe radiographic progression $(222,228-232)$ and a lower response rate to treatment with TNF inhibitors (233235). These aspects have not been studied in JSpA but given the typical age of onset around the time of puberty, and the effect of sex hormones on the immune system and gut microbiome, it seems likely these would influence disease pathogenesis.

Adolescence is also a time of significant skeletal development and therefore increased mechanical strain on the musculoskeletal system. SpA tends to affect sites under the most mechanical strain such as the lower limb and the spine. Extra-articular manifestations of SpA are also found at sites of mechanical stress such as the aortic root and anterior uveal tract (236). In adult SpA, studies have shown more severe disease in those with manual jobs and with certain types of exercise $(237,238)$. One study of patients with JSpA showed nearly a quarter took part in intense physical training (95).

Enthesitis, the primary lesion in early SpA, occurs in susceptible individuals following repetitive microtrauma (239). Mechanical stress has been shown to exacerbate enthesitis in animal models and results in the release of pro-inflammatory cytokines at the enthesis (240). In heathy individuals, the resultant recruitment of innate immune cells leads to healing. However, in SpA, perpetuation of the inflammatory response occurs, perhaps due to IL23/IL17 pathway activation, HLAB27 or gut dysbiosis, resulting in aberrant tissue healing and eventual new bone formation (241). Mechanical stress is heightened during periods of growth and development which may explain the prevalence of enthesitis and peripheral arthritis in children and young people with JSpA. Anatomical studies of the developing skeleton during puberty show that the most important factor in sacral development is the effect of mechanical force which occurs through body weight, load through the femur and strain on the pubic symphysis. Similarly, normal SIJ development is dependent torsion between the ilia and the sacrum $(128,242)$. Changes in SIJ orientation are seen with age and significant differences are found between adults and children and adolescents (243). In addition, distinct pelvic morphology develops in males and females after puberty with larger SIJ surface area in males thought to be related to higher biomechanical loading and larger ligamentous attachments (244). These changes in biomechanical loading and mechanical stress which occur during skeletal development may, in susceptible individuals, result in inflammation at the entheses and later at the SIJs.

\section{CONCLUSION}

There are many similarities between adult SpA and JSpA suggesting that they are a spectrum of the same disease. Key differences in classification criteria, prevalence of clinical features, disease activity, and pathogenesis are evident which are influenced by age, pubertal development, changes in the immune response, and skeletal maturation. Further research is needed in to these factors which may influence treatment stratification for patients with JSpA. Better alignment between paediatric and adult classification and assessment criteria as well as studies encompassing the whole age spectrum of SpA will further our understanding and improve the treatment of this important disease.

\section{AUTHOR CONTRIBUTIONS}

This article was drafted by CF and reviewed and revised by CF, CC, ML, DS, and LW. All authors agree to be accountable for the content of the work.

\section{FUNDING}

CF, CC, ML, DS, and LW are supported in part by a Centre of Excellence grant to the Centre for Adolescent Rheumatology Versus Arthritis from Versus Arthritis (21593); CF was supported by a grant from Versus Arthritis (20762) and the NIHR UCLH Biomedical Research Centre; CC was supported by NIHR UCLH Biomedical Research Centre grants (BRC772/III/EJ/101350, BRC525/III/CC/191350 and BRC773/III/CC/101350) as well as Versus Arthritis (22203 and 21226); DS was supported by the NIHR UCLH Biomedical Research Centre; LW was supported by grants from UKRI Medical Research Council (MR/R013926/1) and Great Ormond Street Children's Charity (VS0518) as well as the NIHR Biomedical Research Centre at GOSH. The views expressed are those of the authors and not necessarily those of the NHS, the NIHR or the Department of Health. 


\section{REFERENCES}

1. Moll JM, Haslock I, Macrae IF, Wright V. Associations between ankylosing spondylitis, psoriatic arthritis, Reiter's disease, the intestinal arthropathies, and Behcet's syndrome. Medicine. (1974) 53:343-64. doi: 10.1097/00005792-197409000-00002

2. Bowness P. Hla-B27. Аnnu Rev Immunol. (2015) 33:29-48. doi: 10.1146/annurev-immunol-032414-112110

3. Stolwijk C, van Onna M, Boonen A, van Tubergen A. Global prevalence of spondyloarthritis: a systematic review and meta-regression analysis. Arthritis Care Res. (2016) 68:1320-31. doi: 10.1002/acr.22831

4. Wilkinson M, Bywaters EG. Clinical features and course of ankylosing spondylitis; as seen in a follow-up of 222 hospital referred cases. Annals Rheumatic Dis. (1958) 17:209-28. doi: 10.1136/ard.17.2.209

5. Petty RE, Southwood TR, Manners P, Baum J, Glass DN, Goldenberg J, et al. International League of Associations for Rheumatology classification of juvenile idiopathic arthritis: second revision, Edmonton, 2001. J Rheumatol. (2004) 31:390-2.

6. Rudwaleit $\mathrm{M}$, van der Heijde $\mathrm{D}$, Landewe R, Akkoc N, Brandt J, Chou CT, et al. The Assessment of SpondyloArthritis International Society classification criteria for peripheral spondyloarthritis and for spondyloarthritis in general. Annals Rheum Dis. (2011) 70:25-31. doi: $10.1136 /$ ard.2010.133645

7. van der Linden S, Valkenburg HA, Cats A. Evaluation of diagnostic criteria for ankylosing spondylitis. A proposal for modification of the New York criteria. Arthritis Rheum. (1984) 27:361-8. doi: 10.1002/art.1780270401

8. Dougados M, Baeten D. Spondyloarthritis. Lancet. (2011) 377:2127-37. doi: 10.1016/S0140-6736(11)60071-8

9. Rosenberg AM, Petty RE. A syndrome of seronegative enthesopathy and arthropathy in children. Arthritis Rheum. (1982) 25:1041-7. doi: 10.1002/art.1780250902

10. Hofer MF, Mouy R, Prieur AM. Juvenile idiopathic arthritides evaluated prospectively in a single center according to the Durban criteria. J Rheumatol. (2001) 28:1083-90.

11. Colbert RA. Classification of juvenile spondyloarthritis: enthesitisrelated arthritis and beyond. Nat Rev Rheumatol. (2010) 6:477-85. doi: 10.1038/nrrheum.2010.103

12. Nigrovic PA, Colbert RA, Holers VM, Ozen S, Ruperto N, Thompson $\mathrm{SD}$, et al. Biological classification of childhood arthritis: roadmap to a molecular nomenclature. Nat Rev Rheumatol. (2021) 17:257-69. doi: 10.1038/s41584-021-00590-6

13. Rusman $T$, van Bentum RE, van der Horst-Bruinsma IE. Sex and gender differences in axial spondyloarthritis: myths and truths. Rheumatology. (2020) 59(Suppl4):438-46. doi: 10.1093/rheumatology/ keaa543

14. Oliveira-Ramos F, Eusebio M, Mourao AF, Furtado C, Campanilho-Marques R. Juvenile idiopathic arthritis in adulthood: fulfilment of classification criteria for adult rheumatic diseases, long-term outcomes and predictors of inactive disease, functional status and damage. RMD Open. (2016) 2:e000304. doi: 10.1136/rmdopen-2016-000304

15. Stanevicha V, Eglite J, Zavadska D, Sochnevs A, Lazareva A, Guseinova D, et al. HLA B27 allele types in homogeneous groups of juvenile idiopathic arthritis patients in Latvia. Pediatr Rheumatol Online J. (2010) 8:26. doi: 10.1186/1546-0096-8-26

16. Kavadichanda CG, Seth G, Kumar G, Gulati R, Negi VS. Clinical correlates of HLA-B*27 and its subtypes in enthesitis-related arthritis variant of juvenile idiopathic arthritis in south Indian Tamil patients. Int J Rheum Dis. (2019) 22:1289-96. doi: 10.1111/1756-185X.13551

17. Brown MA, Kennedy LG, MacGregor AJ, Darke C, Duncan E, Shatford JL, et al. Susceptibility to ankylosing spondylitis in twins: the role of genes, HLA, and the environment. Arthritis Rheum. (1997) 40:1823-8. doi: 10.1002/art.1780401015

18. Smith JA. Update on ankylosing spondylitis: current concepts in pathogenesis. Curr Allergy Asthma Rep. (2015) 15:489. doi: 10.1007/s11882-014-0489-6

19. Ellinghaus D, Jostins L, Spain SL, Cortes A, Bethune J, Han B, et al. Analysis of five chronic inflammatory diseases identifies 27 new associations and highlights disease-specific patterns at shared loci. Nat Genet. (2016) 48:5108. doi: $10.1038 /$ ng. 3528

20. Cortes A, Hadler J, Pointon JP, Robinson PC, Karaderi T, Leo P, et al. Identification of multiple risk variants for ankylosing spondylitis through high-density genotyping of immune-related loci. Nat Genet. (2013) 45:730-8. doi: 10.1038/ng.2667

21. Evans DM, Spencer CC, Pointon JJ, Su Z, Harvey D, Kochan G, et al. Interaction between ERAP1 and HLA-B27 in ankylosing spondylitis implicates peptide handling in the mechanism for HLA-B27 in disease susceptibility. Nat Genet. (2011) 43:761-7. doi: 10.1038/ng0911-919a

22. Hinks A, Martin P, Flynn E, Eyre S, Packham J, Barton A, et al. Subtype specific genetic associations for juvenile idiopathic arthritis: ERAP1 with the enthesitis related arthritis subtype and IL23R with juvenile psoriatic arthritis. Arthritis Res Ther. (2011) 13:R12. doi: 10.1186/ar3235

23. Wellcome Trust Case Control C, Australo-Anglo-American Spondylitis C, Burton PR, Clayton DG, Cardon LR, Craddock N, et al. Association scan of 14,500 nonsynonymous SNPs in four diseases identifies autoimmunity variants. Nat Genet. (2007) 39:1329-37. doi: 10.1038/ng.2007.17

24. Ding $\mathrm{M}$, Guan TJ, Wei CY, Chen BH. Identification of pathways significantly associated with spondyloarthropathy/ankylosing spondylitis using the subpathway method. Mol Med Rep. (2018) 18:3825-33. doi: $10.3892 / \mathrm{mmr} .2018 .9395$

25. Wang Z, Han Y, Zhang Z, Jia C, Zhao Q, Song W, et al. Identification of genes and signaling pathways associated with the pathogenesis of juvenile spondyloarthritis. Mol Med Rep. (2018) 18:1263-70. doi: $10.3892 / \mathrm{mmr} .2018 .9136$

26. Lamot L, Borovecki F, Tambic Bukovac L, Vidovic M, Perica M, Gotovac $\mathrm{K}$, et al. Aberrant expression of shared master-key genes contributes to the immunopathogenesis in patients with juvenile spondyloarthritis. PLOS ONE. (2014) 9:e115416. doi: 10.1371/journal.pone.0115416

27. Sherlock JP, Joyce-Shaikh B, Turner SP, Chao CC, Sathe M, Grein J, et al. IL-23 induces spondyloarthropathy by acting on ROR-gammat+ CD3+CD4-CD8- entheseal resident T cells. Nat Med. (2012) 18:1069-76. doi: $10.1038 / \mathrm{nm} .2817$

28. Zeng L, Lindstrom MJ, Smith JA. Ankylosing spondylitis macrophage production of higher levels of interleukin-23 in response to lipopolysaccharide without induction of a significant unfolded protein response. Arthritis Rheum. (2011) 63:3807-17. doi: 10.1002/art.30593

29. Appel H, Maier R, Bleil J, Hempfing A, Loddenkemper C, Schlichting U, et al. In situ analysis of interleukin-23- and interleukin-12-positive cells in the spine of patients with ankylosing spondylitis. Arthritis Rheum. (2013) 65:1522-9. doi: 10.1002/art.37937

30. Gaur P, Myles A, Misra R, Aggarwal A. Intermediate monocytes are increased in enthesitis-related arthritis, a category of juvenile idiopathic arthritis. Clin Exp Immunol. (2017) 187:234-41. doi: 10.1111/cei.12880

31. Gaur P, Misra R, Aggarwal A. IL-27 levels are low in enthesitis-related arthritis category of juvenile idiopathic arthritis. Clin Exp Rheumatol. (2016) 34:337-42.

32. Melis L, Vandooren B, Kruithof E, Jacques P, De Vos M, Mielants H, et al. Systemic levels of IL-23 are strongly associated with disease activity in rheumatoid arthritis but not spondyloarthritis. Annals Rheum Dis. (2010) 69:618-23. doi: 10.1136/ard.2009.107649

33. Mei Y, Pan F, Gao J, Ge R, Duan Z, Zeng Z, et al. Increased serum IL-17 and IL-23 in the patient with ankylosing spondylitis. Clin Rheumatol. (2011) 30:269-73. doi: 10.1007/s10067-010-1647-4

34. Chen WS, Chang YS, Lin KC, Lai CC, Wang SH, Hsiao KH, et al. Association of serum interleukin-17 and interleukin-23 levels with disease activity in Chinese patients with ankylosing spondylitis. J Chinese Med Association. (2012) 75:303-8. doi: 10.1016/j.jcma.2012.05.006

35. Ugur M, Baygutalp NK, Melikoglu MA, Baygutalp F, Altas EU, Seferoglu B. Elevated serum interleukin-23 levels in ankylosing spondylitis patients and the relationship with disease activity. Nagoya J Med Sci. (2015) 77:621-7.

36. Cuthbert RJ, Watad A, Fragkakis EM, Dunsmuir R, Loughenbury P, Khan $\mathrm{A}$, et al. Evidence that tissue resident human enthesis gammadeltaTcells can produce IL-17A independently of IL-23R transcript expression. Annals Rheum Dis. (2019) 78:1559-65. doi: 10.1136/annrheumdis-2019215210 
37. Ghoreschi K, Laurence A, Yang XP, Tato CM, McGeachy MJ, Konkel JE, et al. Generation of pathogenic $\mathrm{T}(\mathrm{H}) 17$ cells in the absence of TGF-beta signalling. Nature. (2010) 467:967-71. doi: 10.1038/nature09447

38. Jandus C, Bioley G, Rivals JP, Dudler J, Speiser D, Romero P. Increased numbers of circulating polyfunctional Th17 memory cells in patients with seronegative spondylarthritides. Arthritis Rheum. (2008) 58:2307-17. doi: $10.1002 /$ art.23655

39. Shen H, Goodall JC, Gaston JS. Frequency and phenotype of T helper 17 cells in peripheral blood and synovial fluid of patients with reactive arthritis. J Rheumatol. (2010) 37:2096-9. doi: 10.3899/jrheum.100146

40. Singh R, Aggarwal A, Misra R. Th1/Th17 cytokine profiles in patients with reactive arthritis/undifferentiated spondyloarthropathy. J Rheumatol. (2007) 34:2285-90.

41. Wendling D, Cedoz JP, Racadot E, Dumoulin G. Serum IL-17, BMP-7, and bone turnover markers in patients with ankylosing spondylitis. Joint Bone Spine. (2007) 74:304-5. doi: 10.1016/j.jbspin.2006.11.005

42. Mahendra A, Misra R, Aggarwal A. Th1 and Th17 predominance in the enthesitis-related arthritis form of juvenile idiopathic arthritis. J Rheumatol. (2009) 36:1730-6. doi: 10.3899/jrheum.081179

43. Chan AT, Kollnberger SD, Wedderburn LR, Bowness P. Expansion and enhanced survival of natural killer cells expressing the killer immunoglobulin-like receptor KIR3DL2 in spondylarthritis. Arthritis Rheum. (2005) 52:3586-95. doi: 10.1002/art.21395

44. Hreggvidsdottir HS, Noordenbos T, Baeten DL. Inflammatory pathways in spondyloarthritis. Mol Immunol. (2014) 57:28-37. doi: 10.1016/j.molimm.2013.07.016

45. Saxena N, Aggarwal A, Misra R. Elevated concentrations of monocyte derived cytokines in synovial fluid of children with enthesitis related arthritis and polyarticular types of juvenile idiopathic arthritis. J Rheumatol. (2005) 32:1349-53.

46. Bal A, Unlu E, Bahar G, Aydog E, Eksioglu E, Yorgancioglu R. Comparison of serum IL-1 beta, sIL-2R, IL-6, and TNF-alpha levels with disease activity parameters in ankylosing spondylitis. Clin Rheumatol. (2007) 26:211-5. doi: 10.1007/s10067-006-0283-5

47. Pedersen SJ, Sorensen IJ, Garnero P, Johansen JS, Madsen OR, Tvede N, et al. ASDAS, BASDAI and different treatment responses and their relation to biomarkers of inflammation, cartilage and bone turnover in patients with axial spondyloarthritis treated with TNFalpha inhibitors. Annals Rheum Dis. (2011) 70:1375-81. doi: 10.1136/ard.2010.138883

48. Francois RJ, Neure L, Sieper J, Braun J. Immunohistological examination of open sacroiliac biopsies of patients with ankylosing spondylitis: detection of tumour necrosis factor alpha in two patients with early disease and transforming growth factor beta in three more advanced cases. Annals Rheum Dis. (2006) 65:713-20. doi: 10.1136/ard.2005.037465

49. Sieper J, Poddubnyy D. New evidence on the management of spondyloarthritis. Nat Rev Rheumatol. (2016) 12:282-95. doi: $10.1038 /$ nrrheum. 2016.42

50. Wicks IP, Roberts AW. Targeting GM-CSF in inflammatory diseases. Nat Rev Rheumatol. (2016) 12:37-48. doi: 10.1038/nrrheum.2015.161

51. Codarri L, Gyulveszi G, Tosevski V, Hesske L, Fontana A, Magnenat L, et al. RORgammat drives production of the cytokine GM-CSF in helper T cells, which is essential for the effector phase of autoimmune neuroinflammation. Nat Immunol. (2011) 12:560-7. doi: 10.1038/ni.2027

52. El-Behi M, Ciric B, Dai H, Yan Y, Cullimore M, Safavi F, et al. The encephalitogenicity of $\mathrm{T}(\mathrm{H}) 17$ cells is dependent on IL-1- and IL-23-induced production of the cytokine GM-CSF. Nat Immunol. (2011) 12:568-75. doi: $10.1038 /$ ni.2031

53. Al-Mossawi MH, Chen L, Fang H, Ridley A, de Wit J, Yager N, et al. Unique transcriptome signatures and GM-CSF expression in lymphocytes from patients with spondyloarthritis. Nat Commun. (2017) 8:1510. doi: 10.1038/s41467-017-01771-2

54. Piper C, Pesenacker AM, Bending D, Thirugnanabalan B, Varsani H, Wedderburn LR, et al. T cell expression of granulocyte-macrophage colony-stimulating factor in juvenile arthritis is contingent upon Th17 plasticity. Arthritis Rheumatol. (2014) 66:1955-60. doi: 10.1002/art. 38647

55. Smith JA, Barnes MD, Hong D, DeLay ML, Inman RD, Colbert RA. Gene expression analysis of macrophages derived from ankylosing spondylitis patients reveals interferon-gamma dysregulation. Arthritis Rheum. (2008) 58:1640-9. doi: 10.1002/art.23512

56. Fert I, Cagnard N, Glatigny S, Letourneur F, Jacques S, Smith JA, et al. Reverse interferon signature is characteristic of antigen-presenting cells in human and rat spondyloarthritis. Arthritis Rheumatol. (2014) 66:841-51. doi: 10.1002/art.38318

57. Canete JD, Martinez SE, Farres J, Sanmarti R, Blay M, Gomez A, et al. Differential Th1/Th2 cytokine patterns in chronic arthritis: interferon gamma is highly expressed in synovium of rheumatoid arthritis compared with seronegative spondyloarthropathies. Annals Rheum Dis. (2000) 59:2638. doi: 10.1136/ard.59.4.263

58. Gao JW, Zhang KF, Lu JS, Su T. Serum matrix metalloproteinases-3 levels in patients with ankylosing spondylitis. Genet Mol Res. (2015) 14:17068-78. doi: 10.4238/2015.December.16.7

59. Maksymowych WP, Landewe R, Conner-Spady B, Dougados M, Mielants H, van der Tempel $\mathrm{H}$, et al. Serum matrix metalloproteinase 3 is an independent predictor of structural damage progression in patients with ankylosing spondylitis. Arthritis Rheum. (2007) 56:1846-53. doi: 10.1002/art.22589

60. Viswanath V, Myles A, Dayal R, Aggarwal A. Levels of serum matrix metalloproteinase-3 correlate with disease activity in the enthesitis-related arthritis category of juvenile idiopathic arthritis. J Rheumatol. (2011) 38:2482-7. doi: 10.3899/jrheum.110352

61. Mattey DL, Packham JC, Nixon NB, Coates L, Creamer P, Hailwood S, et al. Association of cytokine and matrix metalloproteinase profiles with disease activity and function in ankylosing spondylitis. Arthritis Res Therapy. (2012) 14:R127. doi: 10.1186/ar3857

62. Turina MC, Yeremenko N, Paramarta JE, De Rycke L, Baeten D. Calprotectin (S100A8/9) as serum biomarker for clinical response in proof-of-concept trials in axial and peripheral spondyloarthritis. Arthritis Res Therapy. (2014) 16:413. doi: 10.1186/s13075-014-0413-4

63. Turina MC, Sieper J, Yeremenko N, Conrad K, Haibel H, Rudwaleit M, et al. Calprotectin serum level is an independent marker for radiographic spinal progression in axial spondyloarthritis. Annals Rheum Dis. (2014) 73:1746-8. doi: 10.1136/annrheumdis-2014-205506

64. Jarlborg M, Courvoisier DS, Lamacchia C, Martinez Prat L, Mahler M, Bentow C, et al. Serum calprotectin: a promising biomarker in rheumatoid arthritis and axial spondyloarthritis. Arthritis Res Therapy. (2020) 22:105. doi: 10.1186/s13075-020-02190-3

65. Gupta L, Bhattacharya S, Agarwal V, Aggarwal A. Elevated levels of serum MRP8/14 in ankylosing spondylitis: associated with peripheral arthritis and active disease. Clin Rheumatol. (2016) 35:3075-9. doi: 10.1007/s10067-016-3448-x

66. Rahman MT, Myles A, Gaur P, Misra R, Aggarwal A. TLR4 endogenous ligand MRP8/14 level in enthesitis-related arthritis and its association with disease activity and TLR4 expression. Rheumatology. (2014) 53:270-4. doi: 10.1093/rheumatology/ket375

67. Anink J, Van Suijlekom-Smit LW, Otten MH, Prince FH, van Rossum MA, Dolman KM, et al. MRP8/14 serum levels as a predictor of response to starting and stopping anti-TNF treatment in juvenile idiopathic arthritis. Arthritis Res Therapy. (2015) 17:200. doi: 10.1186/s13075-015-0723-1

68. Moncrieffe H, Ursu S, Holzinger D, Patrick F, Kassoumeri L, Wade A, et al. A subgroup of juvenile idiopathic arthritis patients who respond well to methotrexate are identified by the serum biomarker MRP8/14 protein. Rheumatology. (2013) 52:1467-76. doi: 10.1093/rheumatology/ket152

69. Lopez RN, Leach ST, Lemberg DA, Duvoisin G, Gearry RB, Day AS. Fecal biomarkers in inflammatory bowel disease. J Gastroenterol Hepatol. (2017) 32:577-82. doi: 10.1111/jgh.13611

70. Ma Y, Fan D, Xu S, Deng J, Gao X, Guan S, et al. Calprotectin in spondyloarthritis: a systematic review and meta-analysis. Int Immunopharmacol. (2020) 88:106948. doi: 10.1016/j.intimp.2020.106948

71. Stoll ML, Punaro M, Patel AS. Fecal calprotectin in children with the enthesitis-related arthritis subtype of juvenile idiopathic arthritis. $J$ Rheumatol. (2011) 38:2274-5. doi: 10.3899/jrheum.110508

72. Keat AC, Maini RN, Nkwazi GC, Pegrum GD, Ridgway GL, Scott JT. Role of Chlamydia trachomatis and HLA-B27 in sexually acquired reactive arthritis. Br Med J. (1978) 1:605-7. doi: 10.1136/bmj.1.6113.605

73. Granfors K, Jalkanen S, Lindberg AA, Maki-Ikola O, von Essen R, Lahesmaa-Rantala R, et al. Salmonella lipopolysaccharide in synovial 
cells from patients with reactive arthritis. Lancet. (1990) 335:685-8. doi: 10.1016/0140-6736(90)90804-E

74. Rashid T, Ebringer A. Ankylosing spondylitis is linked to Klebsiella-the evidence. Clin Rheumatol. (2007) 26:858-64. doi: 10.1007/s10067-006-0488-7

75. Merilahti-Palo R, Soderstrom KO, Lahesmaa-Rantala R, Granfors $\mathrm{K}$, Toivanen A. Bacterial antigens in synovial biopsy specimens in yersinia triggered reactive arthritis. Annals Rheum Dis. (1991) 50:87-90. doi: $10.1136 /$ ard.50.2.87

76. Singh YP, Singh AK, Aggarwal A, Misra R. Evidence of cellular immune response to outer membrane protein of Salmonella typhimurium in patients with enthesitis-related arthritis subtype of juvenile idiopathic arthritis. $J$ Rheumatol. (2011) 38:161-6. doi: 10.3899/jrheum.100542

77. Cho I, Blaser MJ. The human microbiome: at the interface of health and disease. Nat Rev Genet. (2012) 13:260-70. doi: 10.1038/nrg3182

78. Costello ME, Ciccia F, Willner D, Warrington N, Robinson PC, Gardiner B, et al. Brief Report: intestinal dysbiosis in ankylosing spondylitis. Arthritis Rheumatol. (2015) 67:686-91. doi: 10.1002/art.38967

79. Breban M, Tap J, Leboime A, Said-Nahal R, Langella P, Chiocchia $\mathrm{G}$, et al. Faecal microbiota study reveals specific dysbiosis in spondyloarthritis. Annals Rheum Dis. (2017) 76:1614-22. doi: 10.1136/annrheumdis-2016-211064

80. Klingberg E, Magnusson MK, Strid H, Deminger A, Stahl A, Sundin J, et al. A distinct gut microbiota composition in patients with ankylosing spondylitis is associated with increased levels of fecal calprotectin. Arthritis Res Therapy. (2019) 21:248. doi: 10.1186/s13075-019-2018-4

81. Stoll ML, Weiss PF, Weiss JE, Nigrovic PA, Edelheit BS, Bridges SL, et al. Age and fecal microbial strain-specific differences in patients with spondyloarthritis. Arthritis Res Therapy. (2018) 20:14. doi: 10.1186/s13075-018-1510-6

82. Tejesvi MV, Arvonen M, Kangas SM, Keskitalo PL, Pirttila AM, Karttunen TJ, et al. Faecal microbiome in new-onset juvenile idiopathic arthritis. Eur J Clin Microbiol Infect Dis. (2016) 35:363-70. doi: 10.1007/s10096-015-2548-x

83. Asquith M, Sternes PR, Costello ME, Karstens L, Diamond S, Martin TM, et al. HLA alleles associated with risk of ankylosing spondylitis and rheumatoid arthritis influence the gut microbiome. Arthritis Rheumatol. (2019) 71:1642-50. doi: 10.1002/art.40917

84. Ospelt C, Gay S. TLRs and chronic inflammation. Int J Biochem Cell Biol. (2010) 42:495-505. doi: 10.1016/j.biocel.2009.10.010

85. Assassi S, Reveille JD, Arnett FC, Weisman MH, Ward MM, Agarwal SK, et al. Whole-blood gene expression profiling in ankylosing spondylitis shows upregulation of toll-like receptor 4 and 5. J Rheumatol. (2011) 38:87-98. doi: 10.3899/jrheum.100469

86. Yang ZX, Liang Y, Zhu Y, Li C, Zhang LZ, Zeng XM, et al. Increased expression of Toll-like receptor 4 in peripheral blood leucocytes and serum levels of some cytokines in patients with ankylosing spondylitis. Clin Exp Immunol. (2007) 149:48-55. doi: 10.1111/j.1365-2249.2007.03396.x

87. De Rycke L, Vandooren B, Kruithof E, De Keyser F, Veys EM, Baeten D. Tumor necrosis factor alpha blockade treatment down-modulates the increased systemic and local expression of Toll-like receptor 2 and Tolllike receptor 4 in spondylarthropathy. Arthritis Rheum. (2005) 52:2146-58. doi: $10.1002 /$ art.21155

88. Myles A, Aggarwal A. Expression of toll-like receptors 2 and 4 is increased in peripheral blood and synovial fluid monocytes of patients with enthesitisrelated arthritis subtype of juvenile idiopathic arthritis. Rheumatology. (2011) 50:481-8. doi: 10.1093/rheumatology/keq362

89. Kruithof E, Van den Bossche V, De Rycke L, Vandooren B, Joos R, Canete JD, et al. Distinct synovial immunopathologic characteristics of juvenile-onset spondylarthritis and other forms of juvenile idiopathic arthritis. Arthritis Rheum. (2006) 54:2594-604. doi: 10.1002/art.22024

90. Carr EJ, Dooley J, Garcia-Perez JE, Lagou V, Lee JC, Wouters C, et al. The cellular composition of the human immune system is shaped by age and cohabitation. Nat Immunol. (2016) 17:461-8. doi: 10.1038/ni.3371

91. Yatsunenko T, Rey FE, Manary MJ, Trehan I, Dominguez-Bello MG, Contreras $\mathrm{M}$, et al. Human gut microbiome viewed across age and geography. Nature. (2012) 486:222-7. doi: 10.1038/nature11053

92. Webb K, Peckham H, Radziszewska A, Menon M, Oliveri P, Simpson F, et al. Sex and pubertal differences in the type 1 interferon pathway associate with both $\mathrm{x}$ chromosome number and serum sex hormone concentration. Front Immunol. (2018) 9:3167. doi: 10.3389/fimmu.2018.03167

93. Chen HA, Chen CH, Liao HT, Lin YJ, Chen PC, Chen WS, et al. Clinical, functional, and radiographic differences among juvenile-onset, adult-onset, and late-onset ankylosing spondylitis. J Rheumatol. (2012) 39:1013-8. doi: $10.3899 /$ jrheum.111031

94. Jadon DR, Ramanan AV, Sengupta R. Juvenile versus adult-onset ankylosing spondylitis - clinical, radiographic, and social outcomes. a systematic review. J Rheumatol. (2013) 40:1797-805. doi: 10.3899/jrheum.130542

95. Lin YC, Liang TH, Chen WS, Lin HY. Differences between juvenile-onset ankylosing spondylitis and adult-onset ankylosing spondylitis. J Chinese Med Association. (2009) 72:573-80. doi: 10.1016/S1726-4901(09)70432-0

96. Stone M, Warren RW, Bruckel J, Cooper D, Cortinovis D, Inman RD. Juvenile-onset ankylosing spondylitis is associated with worse functional outcomes than adult-onset ankylosing spondylitis. Arthritis Rheum. (2005) 53:445-51. doi: 10.1002/art.21174

97. Ozgocmen S, Ardicoglu O, Kamanli A, Kaya A, Durmus B, Yildirim K, et al. Pattern of disease onset, diagnostic delay, and clinical features in juvenile onset and adult onset ankylosing spondylitis. J Rheumatol. (2009) 36:2830-3. doi: 10.3899/jrheum.090435

98. O'Shea FD, Boyle E, Riarh R, Tse SM, Laxer RM, Inman RD. Comparison of clinical and radiographic severity of juvenile-onset versus adultonset ankylosing spondylitis. Annals Rheum Dis. (2009) 68:1407-12. doi: 10.1136/ard.2008.092304

99. Baek HJ, Shin KC, Lee YJ, Kang SW, Lee EB, Yoo CD, et al. Juvenile onset ankylosing spondylitis (JAS) has less severe spinal disease course than adult onset ankylosing spondylitis (AAS): clinical comparison between JAS and AAS in Korea. J Rheumatol. (2002) 29:1780-5.

100. Riley MJ, Ansell BM, Bywaters EG. Radiological manifestations of ankylosing spondylitis according to age at onset. Annals Rheum Dis. (1971) 30:138-48. doi: 10.1136/ard.30.2.138

101. Guo R, Cao L, Kong X, Liu X, Xue H, Shen L, et al. Fever as an initial manifestation of enthesitis-related arthritis subtype of juvenile idiopathic arthritis: retrospective study. PLoS ONE. (2015) 10:e0128979. doi: 10.1371/journal.pone.0128979

102. Butbul Aviel Y, Tyrrell P, Schneider R, Dhillon S, Feldman BM, Laxer R, et al. Juvenile Psoriatic Arthritis (JPsA): juvenile arthritis with psoriasis? Pediatric Rheumatol Online J. (2013) 11:11. doi: 10.1186/1546-0096-11-11

103. Weiss PF, Klink AJ, Behrens EM, Sherry DD, Finkel TH, Feudtner C, et al. Enthesitis in an inception cohort of enthesitis-related arthritis. Arthritis Care Res. (2011) 63:1307-12. doi: 10.1002/acr.20508

104. Rumsey DG, Guzman J, Rosenberg AM, Huber AM, Scuccimarri R, Shiff NJ, et al. Characteristics and course of enthesitis in a juvenile idiopathic arthritis inception cohort. Arthritis Care Res. (2018) 70:303-8. doi: 10.1002/acr.23256

105. Gmuca S, Xiao R, Brandon TG, Pagnini I, Wright TB, Beukelman T, et al. Multicenter inception cohort of enthesitis-related arthritis: variation in disease characteristics and treatment approaches. Arthritis Res Therapy. (2017) 19:84. doi: 10.1186/s13075-017-1297-x

106. Shenoy S, Aggarwal A. Sonologic enthesitis in children with enthesitis-related arthritis. Clin Exp Rheumatol. (2016) 34:143-7. doi: 10.1007/s10067-015-3029-4

107. Marks SH, Barnett M, Calin A. A case-control study of juvenile- and adult-onset ankylosing spondylitis. J Rheumatol. (1982) 9:739-41.

108. Turk M, Hayworth J, Nevskaya T, Pope J. The frequency of uveitis in patients with adult versus childhood spondyloarthritis. RMD Open. (2020) 6:e001196. doi: 10.1136/rmdopen-2020-001196

109. van der Heijde D, Lie E, Kvien TK, Sieper J, Van den Bosch F, Listing J, et al. ASDAS, a highly discriminatory ASAS-endorsed disease activity score in patients with ankylosing spondylitis. Annals Rheum Dis. (2009) 68:1811-8. doi: 10.1136/ard.2008.100826

110. Machado P, Landewe R, Lie E, Kvien TK, Braun J, Baker D, et al. Ankylosing Spondylitis Disease Activity Score (ASDAS): defining cut-off values for disease activity states and improvement scores. Annals Rheum Dis. (2011) 70:47-53. doi: 10.1136/ard.2010.138594

111. Garrett S, Jenkinson T, Kennedy LG, Whitelock H, Gaisford P, Calin A. A new approach to defining disease status in ankylosing spondylitis: the Bath Ankylosing Spondylitis Disease Activity Index. J Rheumatol. (1994) 21:2286-91. 
112. Calin A, Garrett S, Whitelock H, Kennedy LG, O’Hea J, Mallorie P, et al. A new approach to defining functional ability in ankylosing spondylitis: the development of the Bath Ankylosing Spondylitis Functional Index. $J$ Rheumatol. (1994) 21:2281-5.

113. Zanwar A, Phatak S, Aggarwal A. Prospective validation of the Juvenile Spondyloarthritis Disease Activity Index in children with enthesitis-related arthritis. Rheumatology. (2018) 57:2167-71. doi: 10.1093/rheumatology/key246

114. Rachlis AC, Batthish M, Wong B, Anderson M, Duvnjak M, Marcuz M, et al. A24: validation of BASDAI and BASFI in children with spondyloarthritis. Arthritis Rheum. (2014) 66:S38. doi: 10.1002/art.38440

115. Consolaro A, Ruperto N, Bazso A, Pistorio A, Magni-Manzoni S, Filocamo $\mathrm{G}$, et al. Development and validation of a composite disease activity score for juvenile idiopathic arthritis. Arthritis Rheum. (2009) 61:658-66. doi: 10.1002/art.24516

116. Giannini EH, Ruperto N, Ravelli A, Lovell DJ, Felson DT, Martini A. Preliminary definition of improvement in juvenile arthritis. Arthritis Rheum. (1997) 40:1202-9. doi: 10.1002/1529-0131(199707)40:7<1202::AID-ART3>3.0.CO;2-R

117. Weiss PF, Colbert RA, Xiao R, Feudtner C, Beukelman T, DeWitt $\mathrm{EM}$, et al. Development and retrospective validation of the juvenile spondyloarthritis disease activity index. Arthritis Care Res. (2014) 66:177582. doi: 10.1002/acr.22411

118. Jones SD, Porter J, Garrett SL, Kennedy LG, Whitelock H, Calin A. A new scoring system for the Bath Ankylosing Spondylitis Metrology Index (BASMI). J Rheumatol. (1995) 22:1609.

119. van der Heijde D, Landewe R. Selection of a method for scoring radiographs for ankylosing spondylitis clinical trials, by the Assessment in Ankylosing Spondylitis Working Group and OMERACT. J Rheumatol. (2005) 32:20489.

120. Weiss PF, Xiao R, Brandon TG, Biko DM, Maksymowych WP, Lambert RG, et al. Radiographs in screening for sacroiliitis in children: what is the value? Arthritis Res Therapy. (2018) 20:141. doi: 10.1186/s13075-018-1642-8

121. Braun J, Baraliakos X, Buehring B, Kiltz U, Fruth M. Imaging of axial spondyloarthritis. New aspects and differential diagnoses. Clin Exp Rheumatol. (2018) 36(Suppl)114:35-42.

122. Lukas C, Cyteval C, Dougados M, Weber U. MRI for diagnosis of axial spondyloarthritis: major advance with critical limitations 'Not everything that glisters is gold (standard)'. RMD Open. (2018) 4:e000586. doi: 10.1136/rmdopen-2017-000586

123. Jones A, Bray TJP, Mandl P, Hall-Craggs MA, Marzo-Ortega H, Machado PM. Performance of magnetic resonance imaging in the diagnosis of axial spondyloarthritis: a systematic literature review. Rheumatology. (2019) 58:1955-65. doi: 10.1093/rheumatology/kez172

124. Zejden A, Jurik AG. Anatomy of the sacroiliac joints in children and adolescents by computed tomography. Pediatr Rheumatol Online J. (2017) 15:82. doi: 10.1186/s12969-017-0210-0

125. Weiss PF, Maksymowych WP, Lambert RG, Jaremko JL, Biko DM, Paschke J, et al. Feasibility and reliability of the Spondyloarthritis Research Consortium of Canada sacroiliac joint inflammation score in children. Arthritis Res Therapy. (2018) 20:56. doi: 10.1186/s13075-018-1543-x

126. Herregods N, Dehoorne J, Van den Bosch F, Jaremko JL, Van Vlaenderen J, Joos R, et al. ASAS definition for sacroiliitis on MRI in SpA: applicable to children? Pediatric Rheumatol Online J. (2017) 15:24. doi: 10.1186/s12969-017-0159-z

127. Chauvin NA, Xiao R, Brandon TG, Biko DM, Francavilla M, Khrichenko D, et al. MRI of the sacroiliac joint in healthy children. AJR Am J Roentgenol. (2019) 11:1-7. doi: 10.2214/AJR.18.20708

128. Vleeming A, Schuenke MD, Masi AT, Carreiro JE, Danneels L, Willard FH. The sacroiliac joint: an overview of its anatomy, function and potential clinical implications. J Anat. (2012) 221:537-67. doi: 10.1111/j.1469-7580.2012.01564.x

129. Weiss PF, Brandon TG, Bohnsack J, Heshin-Bekenstein M, Francavilla ML, Jaremko JL, et al. Variability in magnetic resonance imaging interpretation of the pediatric sacroiliac joint. Arthritis Care Res. (2020). doi: 10.1002/acr.24206

130. Orr KE, Andronikou S, Bramham MJ, Holjar-Erlic I, Menegotto F, Ramanan AV. Magnetic resonance imaging of sacroiliitis in children: frequency of findings and interobserver reliability. Pediatric Radiol. (2018) 48:1621-8. doi: 10.1007/s00247-018-4185-x

131. Weiss PF, Xiao R, Biko DM, Chauvin NA. Assessment of sacroiliitis at diagnosis of juvenile spondyloarthritis by radiography, magnetic resonance imaging, and clinical examination. Arthritis Care Res. (2016) 68:187-94. doi: 10.1002/acr.22665

132. Bray TJ, Vendhan K, Roberts J, Atkinson D, Punwani S, Sen D, et al. Association of the apparent diffusion coefficient with maturity in adolescent sacroiliac joints. J Magn Reson Imaging. (2016) 44:556-64. doi: 10.1002/jmri.25209

133. Kaeley GS. Visualization of enthesitis by ultrasound: a key diagnostic tool in spondyloarthropathy diagnosis and management. Curr Rheumatol Rep. (2020) 22:48. doi: 10.1007/s11926-020-00927-2

134. Chauvin NA, Ho-Fung V, Jaramillo D, Edgar JC, Weiss PF. Ultrasound of the joints and entheses in healthy children. Pediatric Radiol. (2015) 45:1344-54. doi: 10.1007/s00247-015-3313-0

135. Lin C, Diab M, Milojevic D. Grey-scale ultrasound findings of lower extremity entheses in healthy children. Pediatric Rheumatol Online J. (2015) 13:14. doi: 10.1186/s12969-015-0012-1

136. Dagfinrud H, Kvien TK, Hagen KB. Physiotherapy interventions for ankylosing spondylitis. Cochrane Database Syst Rev. (2008) 23:CD002822. doi: 10.1002/14651858.CD002822.pub3

137. Liang $\mathrm{H}$, Zhang $\mathrm{H}$, Ji H, Wang C. Effects of home-based exercise intervention on health-related quality of life for patients with ankylosing spondylitis: a meta-analysis. Clin Rheumatol. (2015) 34:1737-44. doi: 10.1007/s10067-015-2913-2

138. Song IH, Poddubnyy DA, Rudwaleit M, Sieper J. Benefits and risks of ankylosing spondylitis treatment with nonsteroidal antiinflammatory drugs. Arthritis Rheum. (2008) 58:929-38. doi: 10.1002/art.23275

139. Boersma JW. Retardation of ossification of the lumbar vertebral column in ankylosing spondylitis by means of phenylbutazone. Scand J Rheumatol. (1976) 5:60-4.

140. Wanders A, Heijde D, Landewe R, Behier JM, Calin A, Olivieri I, et al. Nonsteroidal antiinflammatory drugs reduce radiographic progression in patients with ankylosing spondylitis: a randomized clinical trial. Arthritis Rheum. (2005) 52:1756-65. doi: 10.1002/art.21054

141. Sieper J, Listing J, Poddubnyy D, Song IH, Hermann KG, Callhoff J, et al. Effect of continuous versus on-demand treatment of ankylosing spondylitis with diclofenac over 2 years on radiographic progression of the spine: results from a randomised multicentre trial (ENRADAS). Annals Rheum Dis. (2016) 75:1438-43. doi: 10.1136/annrheumdis-2015-207897

142. Weiss A, Minden K, Listing J, Foeldvari I, Sieper J, Rudwaleit M. Course of patients with juvenile spondyloarthritis during 4 years of observation, juvenile part of GESPIC. RMD Open. (2017) 3:e000366. doi: 10.1136/rmdopen-2016-000366

143. Braun J, Zochling J, Baraliakos X, Alten R, Burmester G, Grasedyck K, et al. Efficacy of sulfasalazine in patients with inflammatory back pain due to undifferentiated spondyloarthritis and early ankylosing spondylitis: a multicentre randomised controlled trial. Annals Rheum Dis. (2006) 65:114753. doi: 10.1136/ard.2006.052878

144. Fagerli KM, van der Heijde D, Heiberg MS, Wierod A, Kalstad S, Rodevand $\mathrm{E}$, et al. Is there a role for sulphasalazine in axial spondyloarthritis in the era of TNF inhibition? Data from the NOR-DMARD longitudinal observational study. Rheumatology. (2014) 53:1087-94. doi: 10.1093/rheumatology/ket450

145. Chen J, Lin S, Liu C. Sulfasalazine for ankylosing spondylitis. Cochrane Database Syst Rev. (2014) 2014:CD004800. doi: 10.1002/14651858.CD004800.pub3

146. Haibel H, Brandt HC, Song IH, Brandt A, Listing J, Rudwaleit M, et al. No efficacy of subcutaneous methotrexate in active ankylosing spondylitis: a 16-week open-label trial. Annals Rheum Dis. (2007) 66:419-21. doi: 10.1136/ard.2006.054098

147. Ruperto N, Murray KJ, Gerloni V, Wulffraat N, de Oliveira SK, Falcini F, et al. A randomized trial of parenteral methotrexate comparing an intermediate dose with a higher dose in children with juvenile idiopathic arthritis who failed to respond to standard doses of methotrexate. Arthritis Rheum. (2004) 50:2191-201. doi: 10.1002/art.20288

148. Burgos-Vargas R, Vazquez-Mellado J, Pacheco-Tena C, HernandezGarduno A, Goycochea-Robles MV. A 26 week randomised, double 
blind, placebo controlled exploratory study of sulfasalazine in juvenile onset spondyloarthropathies. Annals Rheum Dis. (2002) 61:941-2. doi: 10.1136/ard.61.10.941

149. Davis JC, Van Der Heijde D, Braun J, Dougados M, Cush J, Clegg DO, et al. Recombinant human tumor necrosis factor receptor (etanercept) for treating ankylosing spondylitis: a randomized, controlled trial. Arthritis Rheum. (2003) 48:3230-6. doi: 10.1002/art.11325

150. van der Heijde D, Kivitz A, Schiff MH, Sieper J, Dijkmans BA, Braun J, et al. Efficacy and safety of adalimumab in patients with ankylosing spondylitis: results of a multicenter, randomized, double-blind, placebo-controlled trial. Arthritis Rheum. (2006) 54:2136-46. doi: 10.1002/art.21913

151. van der Heijde D, Dijkmans B, Geusens P, Sieper J, DeWoody K, Williamson $\mathrm{P}$, et al. Efficacy and safety of infliximab in patients with ankylosing spondylitis: results of a randomized, placebo-controlled trial (ASSERT). Arthritis Rheum. (2005) 52:582-91. doi: 10.1002/art.20852

152. Inman RD, Davis JC, Heijde D, Diekman L, Sieper J, Kim SI, et al. Efficacy and safety of golimumab in patients with ankylosing spondylitis: results of a randomized, double-blind, placebo-controlled, phase III trial. Arthritis Rheum. (2008) 58:3402-12. doi: 10.1002/art.23969

153. Landewe R, Braun J, Deodhar A, Dougados M, Maksymowych WP, Mease PJ, et al. Efficacy of certolizumab pegol on signs and symptoms of axial spondyloarthritis including ankylosing spondylitis: 24-week results of a double-blind randomised placebo-controlled Phase 3 study. Annals Rheum Dis. (2014) 73:39-47. doi: 10.1136/annrheumdis-2013-204231

154. Horneff G, Foeldvari I, Minden K, Trauzeddel R, Kummerle-Deschner JB, Tenbrock K, et al. Efficacy and safety of etanercept in patients with the enthesitis-related arthritis category of juvenile idiopathic arthritis: results from a phase III randomized, double-blind study. Arthritis Rheumatol. (2015) 67:2240-9. doi: 10.1002/art.39145

155. Burgos-Vargas R, Tse SM, Horneff G, Pangan AL, Kalabic J, Goss S, et al. A Randomized, double-blind, placebo-controlled multicenter study of adalimumab in pediatric patients with enthesitis-related arthritis. Arthritis Care Res. (2015) 67:1503-12. doi: 10.1002/acr.22657

156. Horneff G, Fitter S, Foeldvari I, Minden K, Kuemmerle-Deschner J, Tzaribacev N, et al. Double-blind, placebo-controlled randomized trial with adalimumab for treatment of juvenile onset ankylosing spondylitis (JoAS): significant short term improvement. Arthritis Res Therapy. (2012) 14:R230. doi: 10.1186/ar4072

157. Ramanan AV, Dick AD, Jones AP, McKay A, Williamson PR, CompeyrotLacassagne S, et al. Adalimumab plus Methotrexate for Uveitis in Juvenile Idiopathic Arthritis. N Engl J Med. (2017) 376:1637-46. doi: 10.1056/NEJMoa1614160

158. Faubion WA, Dubinsky M, Ruemmele FM, Escher J, Rosh J, Hyams JS, et al. Long-term efficacy and safety of adalimumab in pediatric patients with Crohn's disease. Inflamm Bowel Dis. (2017) 23:453-60. doi: 10.1097/MIB.0000000000001021

159. Papp K, Thaci D, Marcoux D, Weibel L, Philipp S, Ghislain PD, et al. Efficacy and safety of adalimumab every other week versus methotrexate once weekly in children and adolescents with severe chronic plaque psoriasis: a randomised, double-blind, phase 3 trial. Lancet. (2017) 390:40-9. doi: 10.1016/S0140-6736(17)31189-3

160. Marino A, De Souza M, Giani T, Cimaz R. Pharmacotherapy for juvenile spondyloarthritis: an overview of the available therapies. Exp Opin Pharmacother. (2020) 21:2161-8. doi: 10.1080/14656566.2020. 1796970

161. Levin AD, Wildenberg ME, van den Brink GR. Mechanism of action of anti-TNF therapy in inflammatory bowel disease. J Crohns Colitis. (2016) 10:989-97. doi: 10.1093/ecco-jcc/jjw053

162. Levy-Clarke G, Jabs DA, Read RW, Rosenbaum JT, Vitale A, Van Gelder RN. Expert panel recommendations for the use of anti-tumor necrosis factor biologic agents in patients with ocular inflammatory disorders. Ophthalmology. (2014) 121:785-96.e3. doi: 10.1016/j.ophtha.2013. 09.048

163. Poddubnyy D, Listing J, Sieper J. Course of active inflammatory and fatty lesions in patients with early axial spondyloarthritis treated with infliximab plus naproxen as compared to naproxen alone: results from the INFAST study. Arthritis Rheumatol. (2016) 23:CD002822. doi: 10.1002/art. 39690
164. Barkham N, Keen HI, Coates LC, O'Connor P, Hensor E, Fraser AD, et al. Clinical and imaging efficacy of infliximab in HLA-B27-Positive patients with magnetic resonance imaging-determined early sacroiliitis. Arthritis Rheum. (2009) 60:946-54. doi: 10.1002/art.24408

165. Weiss PF, Xiao R, Brandon TG, Pagnini I, Wright TB, Beukelman T, et al. Comparative effectiveness of tumor necrosis factor agents and disease-modifying antirheumatic therapy in children with enthesitis-related arthritis: the first year after diagnosis. J Rheumatol. (2018) 45:107-14. doi: 10.3899/jrheum.170251

166. Song IH, Althoff CE, Haibel H, Hermann KG, Poddubnyy D, Listing J, et al. Frequency and duration of drug-free remission after 1 year of treatment with etanercept versus sulfasalazine in early axial spondyloarthritis: 2 year data of the ESTHER trial. Annals Rheum Dis. (2012) 71:1212-5. doi: 10.1136/annrheumdis-2011-201010

167. Sieper J, Lenaerts J, Wollenhaupt J, Rudwaleit M, Mazurov VI, Myasoutova $\mathrm{L}$, et al. Maintenance of biologic-free remission with naproxen or no treatment in patients with early, active axial spondyloarthritis: results from a 6-month, randomised, open-label follow-up study, INFAST Part 2. Annals Rheum Dis. (2014) 73:108-13. doi: 10.1136/annrheumdis-2013203460

168. Baraliakos X, Listing J, Brandt J, Zink A, Alten R, Burmester G, et al. Clinical response to discontinuation of anti-TNF therapy in patients with ankylosing spondylitis after 3 years of continuous treatment with infliximab. Arthritis Res Therapy. (2005) 7:R439-44. doi: 10.1186/ar1693

169. Otten MH, Prince FH, Twilt M, Ten Cate R, Armbrust W, Hoppenreijs $\mathrm{EP}$, et al. Tumor necrosis factor-blocking agents for children with enthesitis-related arthritis-data from the dutch arthritis and biologicals in children register, 1999-2010. J Rheumatol. (2011) 38:2258-63. doi: 10.3899/jrheum.110145

170. Horton DB, Onel KB, Beukelman T, Ringold S. Attitudes and approaches for withdrawing drugs for children with clinically inactive nonsystemic JIA: a survey of the childhood arthritis and rheumatology research alliance. $J$ Rheumatol. (2017) 44:352-60. doi: 10.3899/jrheum.161078

171. Arends S, van der Veer E, Kamps FB, Houtman PM, Bos R, Bootsma H, et al. Patient-tailored dose reduction of TNF-alpha blocking agents in ankylosing spondylitis patients with stable low disease activity in daily clinical practice. Clin Exp Rheumatol. (2015) 33:174-80.

172. De Stefano R, Frati E, De Quattro D, Menza L, Manganelli S. Low doses of etanercept can be effective to maintain remission in ankylosing spondylitis patients. Clin Rheumatol. (2014) 33:707-11. doi: 10.1007/s10067-013-2372-6

173. van der Heijde D, Landewe R, Einstein S, Ory P, Vosse D, Ni L, et al. Radiographic progression of ankylosing spondylitis after up to two years of treatment with etanercept. Arthritis Rheum. (2008) 58:1324-31. doi: $10.1002 /$ art. 23471

174. van der Heijde D, Landewe R, Baraliakos X, Houben H, van Tubergen A, Williamson P, et al. Radiographic findings following two years of infliximab therapy in patients with ankylosing spondylitis. Arthritis Rheum. (2008) 58:3063-70. doi: 10.1002/art.23901

175. van der Heijde D, Salonen D, Weissman BN, Landewe R, Maksymowych WP, Kupper H, et al. Assessment of radiographic progression in the spines of patients with ankylosing spondylitis treated with adalimumab for up to 2 years. Arthritis Res Therapy. (2009) 11:R127. doi: 10.1186/ar2794

176. Haroon N, Inman RD, Learch TJ, Weisman MH, Lee M, Rahbar MH, et al. The impact of tumor necrosis factor alpha inhibitors on radiographic progression in ankylosing spondylitis. Arthritis Rheum. (2013) 65:2645-54. doi: 10.1002/art.38070

177. Molnar C, Scherer A, Baraliakos X, de Hooge M, Micheroli R, Exer $\mathrm{P}$, et al. TNF blockers inhibit spinal radiographic progression in ankylosing spondylitis by reducing disease activity: results from the Swiss Clinical Quality Management cohort. Annals Rheum Dis. (2018) 77:63-9. doi: 10.1136/annrheumdis-2017-211544

178. Koo BS, Oh JS, Park SY, Shin JH, Ahn GY, Lee S, et al. Tumour necrosis factor inhibitors slow radiographic progression in patients with ankylosing spondylitis: 18-year real-world evidence. Annals Rheum Dis. (2020) 79:132732. doi: 10.1136/annrheumdis-2019-216741

179. Fernandez-Carballido C, Tornero C, Castro-Villegas MC, Galindez E, Garcia-Llorente JF, Garcia-Vivar ML, et al. No radiographic sacroiliitis progression was observed in patients with early spondyloarthritis at 6 years: 
results of the Esperanza multicentric prospective cohort. RMD Open. (2020) 6:e001345. doi: 10.1136/rmdopen-2020-001345

180. Hugle B, Burgos-Vargas R, Inman RD, O'Shea F, Laxer RM, Stimec J, et al. Long-term outcome of anti-tumor necrosis factor alpha blockade in the treatment of juvenile spondyloarthritis. Clin Exp Rheumatol. (2014) 32:42431.

181. Bray TJP, Lopes A, Fisher C, Ciurtin C, Sen D, Hall-Craggs MA. Sacroiliac joint ankylosis in young spondyloarthritis patients receiving biologic therapy: observation of serial magnetic resonance imaging scans. Arthritis Rheumatol. (2019) 71:594-8. doi: 10.1002/art.40750

182. Poddubnyy D, Hermann KG, Callhoff J, Listing J, Sieper J. Ustekinumab for the treatment of patients with active ankylosing spondylitis: results of a 28-week, prospective, open-label, proof-of-concept study (TOPAS). Annals Rheum Dis. (2014) 73:817-23. doi: 10.1136/annrheumdis-2013-204248

183. Mease P. Ustekinumab fails to show efficacy in a phase III axial spondyloarthritis program: the importance of negative results. Arthritis Rheumatol. (2019) 71:179-81. doi: 10.1002/art.40759

184. Kavanaugh A, Puig L, Gottlieb AB, Ritchlin C, You Y, Li S, et al. Efficacy and safety of ustekinumab in psoriatic arthritis patients with peripheral arthritis and physician-reported spondylitis: post-hoc analyses from two phase III, multicentre, double-blind, placebo-controlled studies (PSUMMIT-1/PSUMMIT-2). Annals Rheum Dis. (2016) 75:1984-8. doi: 10.1136/annrheumdis-2015-209068

185. Araujo EG, Englbrecht M, Hoepken S, Finzel S, Kampylafka E, Kleyer A, et al. Effects of ustekinumab versus tumor necrosis factor inhibition on enthesitis: Results from the enthesial clearance in psoriatic arthritis (ECLIPSA) study. Semin Arthritis Rheum. (2019) 48:632-7. doi: 10.1016/j.semarthrit.2018.05.011

186. Mannion ML, McAllister L, Cron RQ, Stoll ML. Ustekinumab as a therapeutic option for children with refractory enthesitis-related arthritis. $J$ Clin Rheumatol. (2016) 22:282-4. doi: 10.1097/RHU.0000000000000408

187. Mease PJ, Gladman DD, Deodhar A, McGonagle DG, Nash P, Boehncke $\mathrm{WH}$, et al. Impact of guselkumab, an interleukin-23 p19 subunit inhibitor, on enthesitis and dactylitis in patients with moderate to severe psoriatic arthritis: results from a randomised, placebo-controlled, phase II study. $R M D$ Open. (2020) 6:e01217. doi: 10.1136/rmdopen-2020-001217

188. Baeten D, Ostergaard M, Wei JC, Sieper J, Jarvinen P, Tam LS, et al. Risankizumab, an IL-23 inhibitor, for ankylosing spondylitis: results of a randomised, double-blind, placebo-controlled, proof-of-concept, dose-finding phase 2 study. Annals Rheum Dis. (2018) 77:1295-302. doi: 10.1136/annrheumdis-2018-213328

189. Baeten D, Baraliakos X, Braun J, Sieper J, Emery P, van der Heijde D, et al. Anti-interleukin-17A monoclonal antibody secukinumab in treatment of ankylosing spondylitis: a randomised, double-blind, placebo-controlled trial. Lancet. (2013) 382:1705-13. doi: 10.1016/S0140-6736(13)61134-4

190. Baraliakos X, Braun J, Deodhar A, Poddubnyy D, Kivitz A, Tahir $\mathrm{H}$, et al. Long-term efficacy and safety of secukinumab $150 \mathrm{mg}$ in ankylosing spondylitis: 5-year results from the phase III MEASURE 1 extension study. RMD Open. (2019) 5:e001005. doi: 10.1136/rmdopen-2019001005

191. Dougados M, Wei JC, Landewe R, Sieper J, Baraliakos X, Van den Bosch F, et al. Efficacy and safety of ixekizumab through 52 weeks in two phase 3 , randomised, controlled clinical trials in patients with active radiographic axial spondyloarthritis (COAST-V and COAST-W). Annals Rheum Dis. (2020) 79:176-85. doi: 10.1136/annrheumdis-2019-216118

192. Mease PJ, Helliwell PS, Hjuler KF, Raymond K, McInnes I. Brodalumab in psoriatic arthritis: results from the randomised phase III AMVISION1 and AMVISION-2 trials. Annals Rheum Dis. (2020) 80:185-93. doi: 10.1136/annrheumdis-2019-216835

193. Nash P, Kirkham B, Okada M, Rahman P, Combe B, Burmester GR, et al. Ixekizumab for the treatment of patients with active psoriatic arthritis and an inadequate response to tumour necrosis factor inhibitors: results from the 24-week randomised, double-blind, placebo-controlled period of the SPIRIT-P2 phase 3 trial. Lancet. (2017) 389:2317-27. doi: 10.1136/annrheumdis-2017-eular.1576

194. Braun J, Baraliakos X, Deodhar A, Poddubnyy D, Emery P, Delicha EM, et al. Secukinumab shows sustained efficacy and low structural progression in ankylosing spondylitis: 4-year results from the MEASURE
1 study. Rheumatology. (2019) 58:859-68. doi: 10.1093/rheumatology/ key375

195. van der Heijde D, Deodhar A, Wei JC, Drescher E, Fleishaker D, Hendrikx T, et al. Tofacitinib in patients with ankylosing spondylitis: a phase II, 16-week, randomised, placebo-controlled, dose-ranging study. Annals Rheum Dis. (2017) 76:1340-7. doi: 10.1136/annrheumdis-2016210322

196. Mease P, Hall S, FitzGerald O, van der Heijde D, Merola JF, Avila-Zapata F, et al. Tofacitinib or adalimumab versus placebo for psoriatic arthritis. $N$ Engl J Med. (2017) 377:1537-50. doi: 10.1056/NEJMoa1615975

197. Sieper J, Porter-Brown B, Thompson L, Harari O, Dougados M. Assessment of short-term symptomatic efficacy of tocilizumab in ankylosing spondylitis: results of randomised, placebo-controlled trials. Annals Rheum Dis. (2014) 73:95-100. doi: 10.1136/annrheumdis-2013-203559

198. Haibel H, Rudwaleit M, Listing J, Sieper J. Open label trial of anakinra in active ankylosing spondylitis over 24 weeks. Annals Rheum Dis. (2005) 64:296-8. doi: 10.1136/ard.2004.023176

199. Song IH, Heldmann F, Rudwaleit M, Haibel H, Weiss A, Braun J, et al. Treatment of active ankylosing spondylitis with abatacept: an open-label, 24-week pilot study. Annals Rheum Dis. (2011) 70:1108-10. doi: 10.1136/ard.2010.145946

200. Song IH, Heldmann F, Rudwaleit M, Listing J, Appel H, Braun $J$, et al. Different response to rituximab in tumor necrosis factor blocker-naive patients with active ankylosing spondylitis and in patients in whom tumor necrosis factor blockers have failed: a twenty-fourweek clinical trial. Arthritis Rheum. (2010) 62:1290-7. doi: 10.1002/art. 27383

201. Amor B, Santos RS, Nahal R, Listrat V, Dougados M. Predictive factors for the longterm outcome of spondyloarthropathies. J Rheumatol. (1994) 21:1883-7.

202. Lopez-Medina C, Ramiro S, van der Heijde D, Sieper J, Dougados M, Molto A. Characteristics and burden of disease in patients with radiographic and non-radiographic axial Spondyloarthritis: a comparison by systematic literature review and meta-analysis. RMD Open. (2019) 5:e001108. doi: 10.1136/rmdopen-2019-001108

203. Bennett AN, McGonagle D, O'Connor P, Hensor EM, Sivera F, Coates LC, et al. Severity of baseline magnetic resonance imaging-evident sacroiliitis and HLA-B27 status in early inflammatory back pain predict radiographically evident ankylosing spondylitis at eight years. Arthritis Rheum. (2008) 58:3413-8. doi: 10.1002/art.24024

204. Maas F, Arends S, van der Veer E, Wink F, Efde M, Bootsma H, et al. Obesity is common in axial spondyloarthritis and is associated with poor clinical outcome. J Rheumatol. (2016) 43:383-7. doi: 10.3899/jrheum. 150648

205. Minden K, Niewerth M, Listing J, Biedermann T, Bollow M, Schontube $\mathrm{M}$, et al. Long-term outcome in patients with juvenile idiopathic arthritis. Arthritis Rheum. (2002) 46:2392-401. doi: 10.1002/art.10444

206. Flato B, Hoffmann-Vold AM, Reiff A, Forre O, Lien G, Vinje O. Longterm outcome and prognostic factors in enthesitis-related arthritis: a case-control study. Arthritis Rheum. (2006) 54:3573-82. doi: 10.1002/art. 22181

207. Donnithorne KJ, Cron RQ, Beukelman T. Attainment of inactive disease status following initiation of TNF-alpha inhibitor therapy for juvenile idiopathic arthritis: enthesitis-related arthritis predicts persistent active disease. J Rheumatol. (2011) 38:2675-81. doi: 10.3899/jrheum. 110427

208. Boiu S, Marniga E, Bader-Meunier B, Mouy R, Compeyrot-Lacassagne $\mathrm{S}$, Quartier $\mathrm{P}$, et al. Functional status in severe juvenile idiopathic arthritis in the biologic treatment era: an assessment in a French paediatric rheumatology referral centre. Rheumatology. (2012) 51:1285-92. doi: 10.1093/rheumatology/kes004

209. Taxter AJ, Wileyto EP, Behrens EM, Weiss PF. Patient-reported outcomes across categories of Juvenile Idiopathic Arthritis. J Rheumatol. (2015) 42:1914-21. doi: 10.3899/jrheum.150092

210. Weiss PF, Beukelman T, Schanberg LE, Kimura Y, Colbert RA. Enthesitis-related arthritis is associated with higher pain intensity and poorer health status in comparison with other categories of juvenile idiopathic arthritis: the Childhood Arthritis and Rheumatology Research 
Alliance Registry. J Rheumatol. (2012) 39:2341-51. doi: 10.3899/jrheum. 120642

211. Berntson L, Damgard M, Andersson-Gare B, Herlin T, Nielsen S, Nordal E, et al. HLA-B27 predicts a more extended disease with increasing age at onset in boys with juvenile idiopathic arthritis. J Rheumatol. (2008) 35:2055-61. doi: 10.1186/1546-0096-6-S1-P57

212. Berntson L, Nordal E, Aalto K, Peltoniemi S, Herlin T, Zak M, et al. HLAB27 predicts a more chronic disease course in an 8-year followup cohort of patients with juvenile idiopathic arthritis. J Rheumatol. (2013) 40:725-31. doi: $10.3899 /$ jrheum. 121257

213. Jadon DR, Shaddick G, Jobling A, Ramanan AV, Sengupta R. Clinical outcomes and progression to orthopedic surgery in juvenile- versus adult-onset ankylosing spondylitis. Arthritis Care Res. (2015) 67:651-7. doi: $10.1002 /$ acr. 22500

214. Gensler LS, Ward MM, Reveille JD, Learch TJ, Weisman MH, Davis JC. Clinical, radiographic and functional differences between juvenileonset and adult-onset ankylosing spondylitis: results from the PSOAS cohort. Annals Rheum Dis. (2008) 67:233-7. doi: 10.1136/ard.2007. 072512

215. Murray KJ, Moroldo MB, Donnelly P, Prahalad S, Passo MH, Giannini EH, et al. Age-specific effects of juvenile rheumatoid arthritis-associated HLA alleles. Arthritis Rheum. (1999) 42:1843-53. doi: 10.1002/1529-0131(199909)42:9<1843::AID-ANR8>3.0.CO;2-M

216. Valiathan R, Ashman M, Asthana D. Effects of ageing on the immune system: infants to elderly. Scand J Immunol. (2016) 83:255-66. doi: 10.1111/sji. 12413

217. Bartlett JA, Schleifer SJ, Demetrikopoulos MK, Delaney BR, Shiflett SC, Keller SE. Immune function in healthy adolescents. Clin Diagn Lab Immunol. (1998) 5:105-13. doi: 10.1128/CDLI.5.1.105-113.1998

218. Yurkovetskiy L, Burrows M, Khan AA, Graham L, Volchkov P, Becker L, et al. Gender bias in autoimmunity is influenced by microbiota. Immunity. (2013) 39:400-12. doi: 10.1016/j.immuni.2013.08.013

219. Gracey E, Yao Y, Green B, Qaiyum Z, Baglaenko Y, Lin A, et al. Sexual dimorphism in the Th17 signature of ankylosing spondylitis. Arthritis Rheumatology. (2016) 68:679-89. doi: 10.1002/art.39464

220. Huang WN, Tso TK, Kuo YC, Tsay GJ. Distinct impacts of syndesmophyte formation on male and female patients with ankylosing spondylitis. Int J Rheum Dis. (2012) 15:163-8. doi: 10.1111/j.1756-185X.2011. 01687.x

221. Van Praet L, Jans L, Carron P, Jacques P, Glorieus E, Colman R, et al. Degree of bone marrow oedema in sacroiliac joints of patients with axial spondyloarthritis is linked to gut inflammation and male sex: results from the GIANT cohort. Annals Rheum Dis. (2014) 73:1186-9. doi: 10.1136/annrheumdis-2013-203854

222. Landi M, Maldonado-Ficco H, Perez-Alamino R, Maldonado-Cocco JA, Citera G, Arturi P, et al. Gender differences among patients with primary ankylosing spondylitis and spondylitis associated with psoriasis and inflammatory bowel disease in an iberoamerican spondyloarthritis cohort. Medicine. (2016) 95:e5652. doi: 10.1097/MD.00000000000 05652

223. de Carvalho HM, Bortoluzzo AB, Goncalves CR, da Silva JA, Ximenes $\mathrm{AC}$, Bertolo $\mathrm{MB}$, et al. Gender characterization in a large series of Brazilian patients with spondyloarthritis. Clin Rheumatol. (2012) 31:687-95. doi: 10.1007/s10067-011-1890-3

224. Webers C, Essers I, Ramiro S, Stolwijk C, Landewe R, van der Heijde D, et al. Gender-attributable differences in outcome of ankylosing spondylitis: longterm results from the Outcome in Ankylosing Spondylitis International Study. Rheumatology. (2016) 55:419-28. doi: 10.1093/rheumatology/ kev340

225. Kilic G, Kilic E, Ozgocmen S. Is there any gender-specific difference in the cut-off values of ankylosing spondylitis disease activity score in patients with axial spondyloarthritis? Int J Rheum Dis. (2017) 20:1201-11. doi: 10.1111/1756-185X.12885

226. Tournadre A, Pereira B, Lhoste A, Dubost JJ, Ristori JM, Claudepierre P, et al. Differences between women and men with recent-onset axial spondyloarthritis: results from a prospective multicenter French cohort. Arthritis Care Res. (2013) 65:1482-9. doi: 10.1002/acr.22001
227. van der Horst-Bruinsma IE, Zack DJ, Szumski A, Koenig AS. Female patients with ankylosing spondylitis: analysis of the impact of gender across treatment studies. Annals Rheum Dis. (2013) 72:1221-4. doi: 10.1136/annrheumdis-2012-202431

228. Lee W, Reveille JD, Davis JC, Learch TJ, Ward MM, Weisman MH. Are there gender differences in severity of ankylosing spondylitis? Results from the PSOAS cohort. Annals Rheum Dis. (2007) 66:633-8. doi: 10.1136/ard.2006.060293

229. van Tubergen A, Ramiro S, van der Heijde D, Dougados M, Mielants H, Landewe R. Development of new syndesmophytes and bridges in ankylosing spondylitis and their predictors: a longitudinal study. Annals Rheum Dis. (2012) 71:518-23. doi: 10.1136/annrheumdis-2011200411

230. Vosse D, Landewe R, Garnero P, van der Heijde D, van der Linden S, Geusens P. Association of markers of bone- and cartilage-degradation with radiological changes at baseline and after 2 years follow-up in patients with ankylosing spondylitis. Rheumatology. (2008) 47:1219-22. doi: 10.1093/rheumatology/ken148

231. Maas F, Spoorenberg A, Brouwer E, Bos R, Efde M, Chaudhry RN, et al. Spinal radiographic progression in patients with ankylosing spondylitis treated with TNF-alpha blocking therapy: a prospective longitudinal observational cohort study. PLoS ONE. (2015) 10:e0122693. doi: 10.1371/journal.pone.0122693

232. Baraliakos X, van den Berg R, Braun J, van der Heijde D. Update of the literature review on treatment with biologics as a basis for the first update of the ASAS/EULAR management recommendations of ankylosing spondylitis. Rheumatology. (2012) 51:1378-87. doi: 10.1093/rheumatology/ kes026

233. Arends S, Brouwer E, van der Veer E, Groen H, Leijsma MK, Houtman PM, et al. Baseline predictors of response and discontinuation of tumor necrosis factor-alpha blocking therapy in ankylosing spondylitis: a prospective longitudinal observational cohort study. Arthritis Res Therapy. (2011) 13:R94. doi: 10.1186/ar3369

234. Gremese E, Bernardi S, Bonazza S, Nowik M, Peluso G, Massara A, et al. Body weight, gender and response to TNF-alpha blockers in axial spondyloarthritis. Rheumatology. (2014) 53:875-81. doi: 10.1093/rheumatology/ket433

235. Lubrano E, Perrotta FM, Manara M, D’Angelo S, Addimanda O, Ramonda R, et al. The sex influence on response to tumor necrosis factor-alpha inhibitors and remission in axial spondyloarthritis. J Rheumatol. (2017) 45:195-201. doi: 10.3899/jrheum.17666

236. Benjamin $\mathrm{M}$, McGonagle $\mathrm{D}$. The anatomical basis for disease localisation in seronegative spondyloarthropathy at entheses and related sites. $J$ Anat. (2001) 199(Pt 5):503-26. doi: 10.1046/j.1469-7580.2001. 19950503.x

237. Ramiro S, Landewe R, van Tubergen A, Boonen A, Stolwijk C, Dougados $\mathrm{M}$, et al. Lifestyle factors may modify the effect of disease activity on radiographic progression in patients with ankylosing spondylitis: a longitudinal analysis. RMD Open. (2015) 1:e000153. doi: 10.1136/rmdopen-2015-000153

238. Ward MM, Reveille JD, Learch TJ, Davis JC, Weisman MH. Occupational physical activities and long-term functional and radiographic outcomes in patients with ankylosing spondylitis. Arthritis Rheum. (2008) 59:822-32. doi: $10.1002 /$ art.23704

239. Watad A, Bridgewood C, Russell T, Marzo-Ortega H, Cuthbert R, McGonagle D. The early phases of ankylosing spondylitis: emerging insights from clinical and basic science. Front Immunol. (2018) 9:2668. doi: $10.3389 /$ fimmu.2018.02668

240. Jacques P, Lambrecht S, Verheugen E, Pauwels E, Kollias G, Armaka $\mathrm{M}$, et al. Proof of concept: enthesitis and new bone formation in spondyloarthritis are driven by mechanical strain and stromal cells. Annals Rheum Dis. (2014) 73:437-45. doi: 10.1136/annrheumdis-2013203643

241. Gracey E, Burssens A, Cambre I, Schett G, Lories R, McInnes IB, et al. Tendon and ligament mechanical loading in the pathogenesis of inflammatory arthritis. Nat Rev Rheumatol. (2020) 16:193-207. doi: 10.1038/s41584-019-0364-x 
242. Solonen KA. The sacroiliac joint in the light of anatomical, roentgenological and clinical studies. Acta Orthop Scand Suppl. (1957) 27:1-127. doi: 10.3109/ort.1957.28.suppl-27.01

243. Coudert P, Dube-Cyr R, Chaumoitre K, Gille O, Vital JM, Jouve JL, et al. Sacroiliac joint morphologic changes from infancy to adulthood. Spine J. (2019) 19:1730-8. doi: 10.1016/j.spinee.2019. 05.009

244. Ebraheim NA, Biyani A. Percutaneous computed tomographic stabilization of the pathologic sacroiliac joint. Clin Orthop Relat Res. (2003) 408:252-5. doi: 10.1097/00003086-20030300000033
Conflict of Interest: The authors declare that the research was conducted in the absence of any commercial or financial relationships that could be construed as a potential conflict of interest.

Copyright (c) 2021 Fisher, Ciurtin, Leandro, Sen and Wedderburn. This is an openaccess article distributed under the terms of the Creative Commons Attribution License (CC BY). The use, distribution or reproduction in other forums is permitted, provided the original author(s) and the copyright owner(s) are credited and that the original publication in this journal is cited, in accordance with accepted academic practice. No use, distribution or reproduction is permitted which does not comply with these terms. 